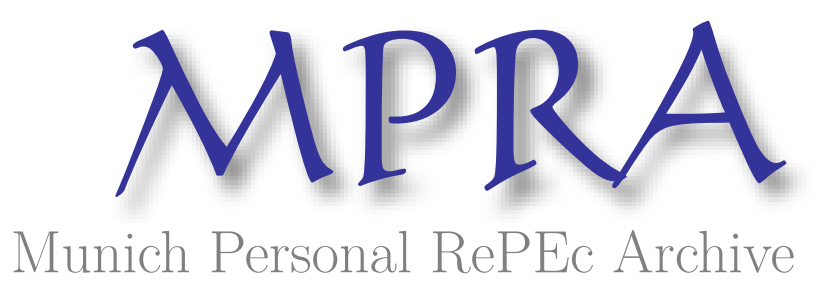

High Frequency Newswire Textual Sentiment: Evidence from international stock markets during the European Financial Crisis

Chouliaras, Andreas

2 March 2015

Online at https://mpra.ub.uni-muenchen.de/62524/

MPRA Paper No. 62524, posted 04 Mar 2015 15:07 UTC 


\title{
High Frequency Newswire Textual Sentiment: Evidence from international stock markets during the European Financial Crisis
}

\author{
Andreas Chouliaras* \\ Luxembourg School of Finance**
}

This version, February 2015

\begin{abstract}
Textual analysis is performed in a total of 13145 high frequency (intraday) news: 6536 news from the Dow Jones Newswires and 6609 news from the Thomson Reuters Newswires. Selected news are Euro-periphery (Portugal, Ireland, Italy, Greece, Spain) crisis-related news which contain a number of keywords in their content and their title. News pessimism as a product of textual analysis sentiment significantly and negatively affects stock returns (an increase in news pessimism is associated with lower stock prices). Media pessimism does not only affect the crisis-hit Euro-periphery countries but also European (Germany, France, Austria, Belgium, Finland, UK, Switzerland, Norway) and overseas (Brazil, Canada, US Dow Jones, US S\&P, Japan, China) stock markets. Stock markets can be very fast when "absorbing" the shocks of media pessimism. Even small time frames such as 30-minutes can be enough for stock prices to be negatively affected by a higher media pessimism. The results are significant in the sense that they provide quantitative evidence that individual countries in crisis can indeed affect not only their own stock markets, not only markets close to them, but also overseas markets from both sides of the globe. The media (and especially newswires which release news with extreme speeds and coverage) provide a channel through which "bad" news are instantaneously circulated and provide worldwide "shocks" to stock prices in extremely small time windows (even 30 minutes). If one takes into account the number of news examined (13145), small shocks can ultimately add up to pretty significant losses for all parties involved (individual investors, funds, corporations, nations). Stock market shocks from Athens, Lisbon, Madrid, Dublin and Rome are "felt" quite fast not only in Berlin, Paris, Vienna, London and Zurich, but also in New York, Toronto, Tokyo and Hong Kong.
\end{abstract}

JEL classification: G01, G14, G15, D83.

Keywords: Financial Crisis, Textual Analysis, News Flow, Financial Sentiment, High Frequency, Dow Jones, Thomson Reuters.

\footnotetext{
* Corresponding author. E-mail address: andreas.chouliaras@uni.lu ** Luxembourg School of Finance, 4, rue Albert Borschette, 1246 Luxembourg.
} 


\section{Introduction}

The Euro-crisis has been at the center of attention for the financial press since the Euro-crisis started, around the end of 2009. Thousands of news articles were written about the Euro-periphery countries (Portugal, Ireland, Italy, Greece, Spain), whose vulnerabilities led to bailout packages, either at the sovereign or the banking level. There has been fierce debate on whether these countries could make it or not, how bad their finances and how uncompetitive they were, whether they should part ways with the common currency area (Eurozone), and whether bad news about them might propagate and affect the rest of the European countries, causing a domino effect.

Previous research regarding news and events concerning the Euro-crisis (e.g. Arezki, Candelon, and Sy (2011), Beetsma, Giuliodori, de Jong, and Widijanto (2013), Mink and De Haan (2013)) mainly dealt with the impact of official news announcements such as sovereign debt rating changes, using dummy variables to denote the occurrence of events, or arbitrarily defining events and news as "good" or "bad". Nevertheless, such specific announcements give at best a partial and at worst a biased view of the impact of information on market prices since they do not reflect all available news and in many cases they are anticipated by market participants. Classifying events arbitrarily is problematic because it depends entirely on the perceptions and beliefs of the researcher(s) who classify the news, while it also neglects the degree of negative (or positive, or uncertain) information, dealing only with the extreme parts of the sentiment spectrum, and completely ignoring all values in between. We attempt to shed light on the impact of the News Flow imbedded in newswires articles. Chouliaras and Grammatikos (2013) study the effect of news sentiment on the probability of extreme stock market returns on a daily basis. But a more high-frequency analysis is also of interest, especially nowadays that the advance of technology allows market participants to conduct decision making in a much speedier manner. Is a whole trading day necessary for markets to "absorb" the negative media content (pessimism), or are smaller time frames enough? To our knowledge, this is the first paper to study the high-frequency effects of the Euro-crisis using data with are timestamped up to milliseconds; second, we incorporate the two biggest international newswires (Thomson Reuters Newswire and Dow Jones Newswire) and we use a rather elaborate method to select news items relevant for the topic of the Euro-crisis under investigation; third, we develop and test different metrics of news relevance; fourth, we specifically examine the impact of News Flow about the peripheral countries on international intraday stock returns. This way we answer the question of whether afterall the Euro-periphery financial sentiment does indeed significantly affect the other countries financial assets returns, which is the main concern of financial discussions and policy making since the advent of the Euro-crisis.

We find that the News Flow about the financial crisis significantly affect not only the Europeriphery but also international stock markets. The effect is not only limited in European Union countries, but also overseas financila markets are affected (USA, Japan, China). A higher negative (and pessimistic) content regarding the Euro-crisis is associated with lower stock returns even when considering a very small time frame (30 minutes after the news were released).

The rest of this paper is organized as follows. Section 2 presents the related textual-analysis literature. Section 3 presents the data. Section 4 presents the model specification and we explain how we study the effect of News Sentiment in a cross-country setting. Section 5 provides the empirical results. Section 6 concludes. 


\section{Related Literature}

The study of News Flow has attracted the researchers' interest rather recently with the advent of Data Mining and Sentiment Analysis techniques. The strong interest in this area has been demonstrated by the recent creation of companies and commercial products specialized in the production of financial sentiment (see e.g., RavenPack ${ }^{1}$ and Thomson Reuters News Analytics ${ }^{2}$ ). As far as the finance literature is concerned, the pioneering work of Tetlock (2007) uses textual analysis (based on the Harvard psychosocial dictionary) of a Wall Street Journal column, and associates the content of the news with the Dow Jones returns, using vector autoregressions (VARs). He finds that media pessimism has predictive power on market returns, while reversion effects occur and extreme absolute values of pessimism predict higher trading volumes. Loughran and McDonald (2011) develop financeoriented word lists by fine-tuning the Harvard dictionary, and correlate textual analysis variables with 10-Ks filing returns, trading volume, volatility and other characteristics. Other studies report evidence of predictive power of stock message boards and major financial columns on volatility, returns and volume (Antweiler and Frank (2004), Chen, De, Hu, and Hwang (2013)). The related literature also studies the effect of returns on media content Garcia (2012), the effect of media content on returns during recessions and expansions Garcia (2013)), while a high level of similarity in firm-specific news is found to provoke higher trading aggressiveness of individual investors (Tetlock (2011)). Boudoukh, Feldman, Kogan, and Richardson (2013) find that news that can be identified and classified in certain categories have a higher impact on stock markets than unidentified news. Another area of research has been the field of corporate earnings, where Tetlock, Saar-Tsechansky, and Macskassy (2008) find that a higher percentage of negative words in news about specific firms predicts lower quarterly earnings. Furthermore, textual analysis has been used for the study of initial public offerings (IPOs). Loughran and McDonald (2013) find that higher uncertainty in filings affect first-day returns and ex post volatility, Jegadeesh and Wu (2013) give different weights on words based on the market reactions that they caused and $\mathrm{Li}$ (2010) studies the effect of forward-looking statements in corporate filings on future earnings and liquidity. Finally, Ahern and Sosyura (2014) show evidence of firms manipulating media coverage to achieve better stock prices during mergers and acquisitions negotiations.

Our study is related to Tetlock (2007), Garcia (2013), Garcia (2012) and Chouliaras and Grammatikos (2013) as far as the analysis of News Flow is concerned. The main contributions to the previous literature are: first and foremost, we employ a database of 13145 news articles from the two biggest international newswires (Dow Jones and Thomson Reuters).

Since it is well accepted that the most vulnerable eurozone countries -the Euro-periphery group- were the most badly hit by the Euro-crisis, our main interest is to study for the effect of Euro-periphery news sentiment to international stock markets.

\section{The Data}

The financial data we employ come from Thomson Reuters Tick History (TRTH) ${ }^{3}$. We use data on stock indices for various European countries (Portugal, Ireland, Italy, Greece, Spain, Austria, Belgium, Finland, Germany, United Kingdom, Switzerland, Norway) but also overseas stock markets (US S\&P, US Dow Jones, China, Japan, Brazil, Canada).

\footnotetext{
${ }^{1}$ http://www.ravenpack.com/

${ }^{2}$ http://www.machinereadablenews.com/

${ }^{3}$ Thomson Reuters Tick History can be found at: http://thomsonreuters.com/tick-history/
} 


\section{The Methodology}

\subsection{Preprocessing the financial data}

As far as the processing of the financial data is concerned, we create MySQL databases in order to be able to handle the huge amount of data. Furthermore, we process the data so as to keep one entry per minute. Specifically, we keep the first entry for every minute. Then, since we are working in 30-minute intervals, we keep one entry per five (30) minutes. Since our news data are time-stamped in a minute basis, we first of all make sure both news data and financial data are in the same time zone. We bring all data in the Greenwich Mean Time (GMT) timezone. The news data were downloaded in a time zone of GMT+1, thus we subtract one hour from every news item. Some financial data are in GMT+2 (or for some countries from GMT-9 to GMT+9), and we subtract 2 hours from this news, so that every time series is finally in a GMT timezone. Moreover, we make sure we have an aggregate news metric for every financial data point. Thus, if in the interval between two news we have more than one news item, we calculate the average percentages of these news items, so that for every financial price we have one value for the respective news that fall in this time interval between the release of two consecutive prices. The table with the performed "time alignments" follows:

Insert Table 2 here

After this time alignment is performed, every time series is brought to a common time zone (GMT). Thus, we are able to proceed studying the 30-minute effect of media content on high frequency stock returns. After we perform this "time zone alignment" between news and stock markets (and bring every time series in a GMT time zone), we are able to start combining the news with the financial data. For a trader/investor, to read a news item, process it, place an order, and for this order to be executed and affect stock prices, a reasonable time frame is required. Thus, we keep prices every 30 minutes (half an hour). If between the 30-minutes time intervals more than one news are released, we calculate the average positive, negative and pessimism factors for all these news. If news items were released during non-operating hours, we "attach" these news to the next price available (i.e. the first price of the next trading day)

\subsection{News Flow}

One can conjecture that changes in relevant information flows is one of the significant factors that affect stock prices. Obtaining usable indicators of information flows and their sentiment and relating them directly to the (extreme) market returns is the focus of this paper. This approach should provide interesting contributions to the relatively new strand in the finance literature that examines directly how information is assimilated by and affects market prices.

In this context we analyze the content of news stories in the newswires. As far as the news stories are concerned, we extract and analyze from Dow Jones Factiva ${ }^{4}$ news articles covering the time period from December 1st, 2009 till November 28nd, 2012. We collect news articles from two sources: the Dow Jones Newswires and the Thomson Reuters Newswire. We use these two newswires because because they are undoubtedly among the most popular providers of real-time news worldwide. Dow Jones Newswires and Thomson Reuters give news items in newswires form, capturing news in real time. For

\footnotetext{
${ }^{4}$ Dow Jones Factiva can be found in http://www.dowjones.com/factiva/index.asp
} 
each country the relevant stories are obtained by a query searching for news that include the name of the Euro-periphery country plus one of the following terms each time: crisis, debt, economy, deficit, default. For example, for Greece the news were retrieved by searching for news stories containing any of the terms:

- "greek crisis"

- "greek debt"

- "greek economy"

- "greek deficit"

- "greek default"

The same applies to all five Euro-periphery countries. The importance of these search terms is straightforward: A news item that contains the term Greek crisis is certainly related to the crisis in Greece. "Greek debt" is relevant since the european crisis is also a debt crisis. The search term "greek economy" is included in order to capture the stories about the nation economy. The "greek deficit" component is included since a lot of discussion is made around the deficits of the countries and the deficit is obviously one of the main factors to assess the financial performance of a nation. Finally, the "greek default" component captures the sovereign default risk debate, since the fear of countries defaulting elevated at various time points during the crisis.

\subsection{Preprocessing the news data}

As a first step we exclude duplicate articles that can reach very high numbers. Especially in newswires (Dow Jones Newswires and Thomson Reuters), it is very common that the same (or highly similar) pieces of information are redistributed, even up to ten times or more. This can cause problems since there is the possibility that a small number of news dominates the news sample, simply because it is being delivered multiple times, with none (or insignificant) changes. Many times the same information is published in these editions, even with different dates, since the time zone differences can be quite significant. Thus, since we want to study the unique impact of information at the day it was first released, we keep the news item published first and discard all duplicates after the distribution of the first news item.

\subsection{Keywords in titles as a determinant of news items relevance}

Another issue of concern has to do with the fact that news items that contain a set of keywords, do not necessarily concern only this topic. This is true especially for newswires. Very often multiple pieces of information are released through newswires in the same news item, covering multiple topics, each one of them occupying no more than a few lines of the overall news item. To deal with this problem, we select only items that contain one or more of a set of keywords in their title. The title is signalling the content of the article. Thus, we expect articles that contain one or more of these keywords in the title, to be of higher relevance to our topic, than selecting all articles that contain one or more keywords in the text, but may refer to many other topics as well. The title keywords for Greece are the following: "greece", "greece's", "greek", "greeks", "hellas", "hellenic". Similar keywords are used for the other four Euro-periphery countries. After these preprocessing steps are applied, the news sources and the total number of news items appear in Table 3, having a total of 13145 news items: 
We notice that most of the news concern Greece: Out of 13145, a total of 8128 concern the greek crisis. This is well understood since Greece is the country that was most badly hurt, and naturally the financial press took a great interest in covering news concerning the greek financial troubles as they evolved through time. After Greece, the most news were about Spain (1822), followed by Ireland (1319), Italy (1268) and finally, Portugal (608). Surprisingly, the overall number of articles released from Reuters and Dow Jones are very close to each other (6609 and 6536 respectively). This is an indicator that more or less these two newswires covered in a similar fashion (in terms of news volume) the Euro-crisis, and are also an indicator that our keyword filters and not biased in terms of selecting news from the one versus the other newswire.

The graphical plot of the number of news during each time period is shown in Figure 1:

Fig. 1.

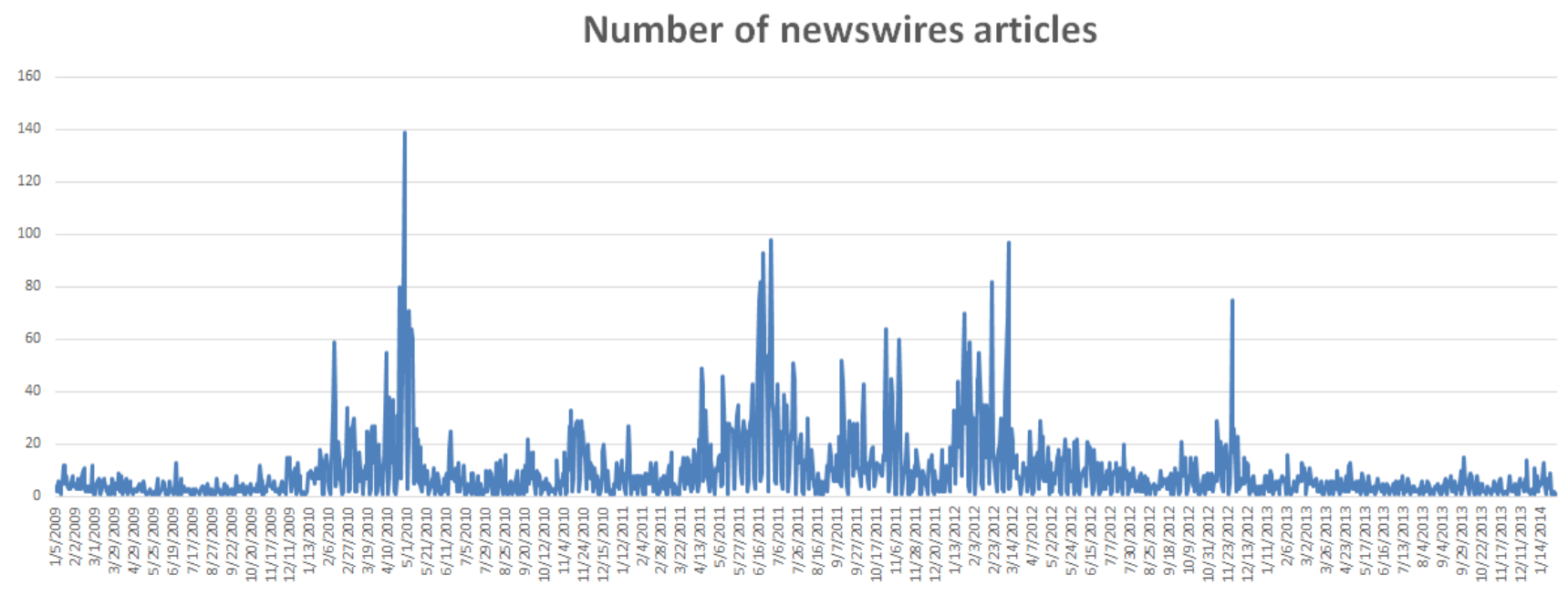

Naturally, the number of news is not constant through times, as the Euro-crisis escalates and "calms down" throughout various points in time. We see "spikes" in terms of the number of news. At least four or five points in time are visible where a much higher number of news are released: the biggest is on May 2010 (when the Greek bailout was announced) with a maximum of 140 news articles released in one single day. This number of news is very high given the fact that we already performed two series of filtering for the news (both for the content and the titles of the news - only the title filtering removes more than half of the news, while the duplicate filter also removes around half of news, thus in this day actually more than 500 crisis-related news were released, a factor indicating the extremely high interest the Euro-crisis drew in the financial press). Another spike occurs around July 2011, an important period given the Euro-summit which took place in 22 July 2011 to guarantee a new bailout plan for Greece ${ }^{5}$. Another spike occurs around March 2012, when the new bailout of

\footnotetext{
${ }^{5}$ For example, an article covering the event from Guardian: http://www.theguardian.com/business/2011/jul/21/ european-debt-crisis-summit-euro
} 
Greece was finally granted ${ }^{6}$. Finally, another spike occurs at November 2012, when Eurozone ministers agreed to cut the Greek debt by another 40 billion euros and to release 44 billions in bailout money and $\operatorname{aid}^{7}$.

\subsection{Textual Analysis}

As a next step, using textual analysis, based on the Loughran and McDonald (2011) dictionary ${ }^{8}$, we measure the positive media content as in Garcia (2012) and Garcia (2013): $G_{i}=\sum_{i} \frac{g_{i}}{w_{i}}$, calculated as the percentage of positive words over the total number of words of every news article. The symbol $g_{i}$ stands for the number of positive words in the article, and $w_{i}$ stands for the total number of words in the article. We do the same for the negative words, obtaining the negative media content as $B_{t}=\sum_{i} \frac{b_{t}}{w_{t}}$, with $b_{i}$ denoting the negative words in the article. Thus, we obtain the Pessimism of article i:

$$
\text { Pessimism }_{i}=B_{i}-G_{i}
$$

The Pessimism is calculated for every article. If more than one news are released between two financial prices (30 minute intervals), we also calculate the Average Pessimism from all the articles that fall in this interval. Another metric we use is the News Count $\left(N_{t}\right)$ : This is the total number of articles released between two financial prices (30 minute intervals) regarding any of the queries we are interested in.

The summary statistics for the media content (positive, negative, pessimism) and the stock markets appear in Table 4:

Insert Table 4 here

We see that stock markets have mean returns of 0 (normal since we are talking about 30-minute returns), while the media have positive means (3.2\% for the negative, $0.7 \%$ for the positive and $2.4 \%$ for the pessimism media content).

\section{Empirical Findings}

The model we employ the study the effect of news in high frequency stock returns is the following:

$$
R_{t}=a_{1}+b_{1} M_{t}+\sum_{i=1}^{5} c_{i} R_{t-i}
$$

where $M_{t}$ takes the value of:

- the positive $\left(G_{t}\right)$

- the negative $\left(B_{t}\right)$

- the pessimism $\left(P_{t}\right)$ and

- the news count $\left(N_{t}\right)$

\footnotetext{
${ }^{6} \mathrm{An}$ article by BBC covering the event: http://www.bbc.com/news/business -17338100

${ }^{7}$ Another article by BBC covering the event: http://www.bbc.com/news/business -13798000

${ }^{8}$ The dictionary can be found at http://www3.nd.edu/ mcdonald/Word_Lists.html
} 
of the previous 30-minute interval respectively. we are primarily interested in the sign, the coefficient and the statistical significance of the $b_{1}$ coefficient. We control for five lags of returns (i.e. five 30-minute lagged returns for every stock market) to deal with autocorrelation in the returns. The regressions we perform are robust (using the Huber-White sandwich estimators) to deal with autocorrelation, heteroskedasticity, heterogeneity and lack of normality.

The results of the robust regressions appear in Tables 5 to 23 :

Insert Tables from 5 until 23 here

Tables from 5 until 23 contain the results for the robust regressions which study the 30-minutes effect of news in international stock markets. Tables 5 to 9 concern the effect on all five Euro-periphery countries, which are the most badly hit European countries during the Euro-crisis. The negative and the pessimism content is significant for all five Euro-periphery countries, and has a negative sign. This means that a higher negative content and a higher pessimism is associated with lower stock prices 30 minutes later. The effect is stronger for Portugal and Greece, followed by Ireland, Italy and Spain. An increase of 1 percent in the news pessimism decreases stock prices for Greece by $0.0194 \%$. This drop can be quite significant given the fact that the average pessimism is $2.4 \%$ while the maximum is $13.6 \%$. Also, given the fact that we are talking about 30-minutes returns, and about thousands of news, the effect can be quite significant when many news are released between price intervals. Furthermore, given the fact that these market capitalisations are hundres of billions of Dollars (and even trillions for some countries), these coefficients can become very significant in terms of the magnitude of losses for investors. Most of the positive content coefficients are insignificant, which is a finding consistent with the previous literature (Tetlock (2007), Garcia (2012), Loughran and McDonald (2011)), because investors tend to discount positive content. In the cases that the coefficient is significant, the coefficient has a positive sign, which means that a higher positive content increases stock returns.

Tables 10 until 17 present the results for European stock indices. We see that the effect is not only for the five Euro-periphery countries, but also for these eight (8) European countries (Germany, France, Austria, Belgium, Finland, United Kingdom, Switzerland, Norway). The effect is stronger for France and Austria, then for Belgium, Finland and the United Kingdom, while it is less significant for Germany, and Switzerland. Nevertheless, the effect is statistically significant (at least at the $90 \%$ significance level for all these European stock markets), with the coefficients once more being negative, indicating that a higher media pessimism is associated with lower stock prices at maximum 30 minutes after the news were released.

Tables 18 to 23 report the results for overseas stock markets (Brazil, Canada, US Dow Jones, US S\&P, Japan, China). Once more we find statistically significant coefficients for the negative and the pessimistic media content, with the effect being most significant for US (both $\mathrm{S} \% \mathrm{P}$ and Dow Jones) and Japan, while it is not as strong (but is still significant) for Brazil, Canada, and China. Once more, the coefficient of pessimism is negative, in other words a higher media pessimism is associated with lower stock prices 30 minutes later. Some markets do not operate at the same time zones, but news still get published throughout the day. For those countries that the market was not operating while the news was released, the news is attached in the next price available. This means that when the market operates again, the news still affects prices in this market. 


\section{Conclusion}

Textual analysis is performed in a total of 13145 news in total: 6536 news from the Dow Jones Newswires and 6609 news from Thomson Reuters. Selected news are crisis-related news which contain a number of keywords in their content and their title. News pessimism significantly affects stock returns (an increase in news pessimism is associated with lower stock prices). Media pessimism does not only affect the crisis-hit Euro-periphery countries (Portugal, Ireland, Italy, Greece and Spain) but also European (Germany, France, Austria, Finland, Belgium, UK, Switzerland) and overseas (US, China, Japan) stock markets. Stock markets can be very fast when "absorbing" the shocks of media pessimism. Even small time frames such as 30-minutes can be enough for stock prices to be negatively affected by a higher media pessimism. Especially the findings for overseas markets are rather surprising: Euro-crisis related news do not only affect the Euro-periphery countries, not only the European equity markets, but also markets which are very far away, such as markets on the West of Europe - the United States (both S\&P and Dow Jones), Canada, Brazil, but also markets at the East - Japan and China. This provides that indeed the significance of the Euro-crisis spans far across the "narrow" borders of the Euro-periphery countries, and even the borders of Europe, since markets all over the globe are affected on "real time" by high frequency news released through international newswires. Stock market "shocks" are not only "felt" to Athens, Lisbon, Rome, Dublin, Madrid, but also to Berlin, Paris, London, Vienna, New York, Toronto, Hong Kong and Tokyo, among others. 


\section{References}

Ahern, K. R., Sosyura, D., 2014. Who writes the news? corporate press releases during merger negotiations. The Journal of Finance 69, 241-291.

Antweiler, W., Frank, M. Z., 2004. Is all that talk just noise? the information content of internet stock message boards. The Journal of Finance 59, 1259-1294.

Arezki, R., Candelon, B., Sy, A., 2011. Sovereign rating news and financial markets spillovers: Evidence from the european debt crisis. IMF working papers pp. 1-27.

Beetsma, R., Giuliodori, M., de Jong, F., Widijanto, D., 2013. Spread the news: The impact of news on the european sovereign bond markets during the crisis. Journal of International Money and Finance $34,83-101$.

Boudoukh, J., Feldman, R., Kogan, S., Richardson, M., 2013. Which news moves stock prices? a textual analysis. Tech. rep., National Bureau of Economic Research.

Chen, H., De, P., Hu, J., Hwang, B.-H., 2013. Wisdom of crowds: The value of stock opinions transmitted through social media. Review of Financial Studies .

Chouliaras, A., Grammatikos, T., 2013. News flow, web attention and extreme returns in the european financial crisis .

Garcia, D., 2012. The kinks of financial journalism .

Garcia, D., 2013. Sentiment during recessions. The Journal of Finance 68, 1267-1300.

Jegadeesh, N., Wu, D., 2013. Word power: A new approach for content analysis. Journal of Financial Economics 110, 712-729.

Li, F., 2010. The information content of forward-looking statements in corporate filings - a naïve bayesian machine learning approach. Journal of Accounting Research 48, 1049-1102.

Loughran, T., McDonald, B., 2011. When is a liability not a liability? textual analysis, dictionaries, and 10-ks. The Journal of Finance 66, 35-65.

Loughran, T., McDonald, B., 2013. Ipo first-day returns, offer price revisions, volatility, and form s-1 language. Journal of Financial Economics .

Mink, M., De Haan, J., 2013. Contagion during the greek sovereign debt crisis. Journal of International Money and Finance 34, 102-113.

Tetlock, P. C., 2007. Giving content to investor sentiment: The role of media in the stock market. The Journal of Finance 62, 1139-1168.

Tetlock, P. C., 2011. All the news that's fit to reprint: Do investors react to stale information? Review of Financial Studies 24, 1481-1512.

Tetlock, P. C., Saar-Tsechansky, M., Macskassy, S., 2008. More than words: Quantifying language to measure firms' fundamentals. The Journal of Finance 63, 1437-1467. 
Table 1: Stock index used for every country

\begin{tabular}{lr}
\hline Country & Stock Index used \\
\hline \hline Portugal & PSI 20 \\
Ireland & ISEQ \\
Italy & FTSE MIB \\
Greece & ASE \\
Spain & IBEX 35 \\
Germany & XETRA DAX \\
France & CAC 40 \\
Austria & ATX \\
Finland & OMX \\
Belgium & BEL 20 \\
UK & FTSE 100 \\
Switzerland & SMI \\
Norway & OBX \\
Brazil & BOVESPA \\
Canada & S\&P TSX 60 \\
USA & Dow Jones \\
USA & S\&P 500 \\
Japan & Nikkei 225 \\
China & Hong Kong Hang Seng \\
\hline
\end{tabular}


Table 2: Timezones for intraday news and financial data

\begin{tabular}{lrrr}
\hline Source & Original Timezone & Add/Subtract & Timezone after processing \\
\hline \hline News from Dow Jones Factiva & GMT+1 & Subtract one hour (-1) & GMT \\
Portugal & GMT+1 & Subtract one hour (-1) & GMT \\
Ireland & GMT & & GMT \\
Italy & GMT & & GMT \\
Greece & GMT+2 & Subtract two hours (-2) & GMT \\
Spain & GMT+1 & Subtract one hour (-1) & GMT \\
Germany & GMT+1 & Subtract one hour (-1) & GMT \\
France & GMT+1 & Subtract one hour (-1) & GMT \\
Austria & GMT+1 & Subtract one hour (-1) \\
Finland & GMT+2 & Subtract two hours (-2) & GMT \\
Belgium & GMT+1 & Subtract one hour (-1) & GMT \\
UK & GMT & & GMT \\
Switzerland & GMT+1 & Subtract one hour (-1) & GMT \\
Norway & GMT+1 & Subtract one hour (-1) & GMT \\
Brazil & GMT-2 & Add two hours (+2) & GMT \\
Canada & GMT-5 & Add five hours (+5) & GMT \\
USA (S\&P) & GMT-6 & Add six hours (+6) & GMT \\
USA (Dow Jones) & GMT-5 & Add five hours (+5) & GMT \\
Japan & GMT+9 & Subtract nine hours (-9) & GMT \\
China & GMT+8 & Subtract eight hours (-8) & GMT \\
\hline
\end{tabular}

Note: Stock markets and news are in different time zones. To be able to examine the effect of news on an intraday setting, we need to bring every time series on a common time zone, making the necessary adjustments (adding or subtracting hours respectively). 
Table 3: Number of news per country/source.

\begin{tabular}{lrrrrrr}
\hline Source & Portugal & Ireland & Italy & Greece & Spain & Total \\
\hline \hline Dow Jones Newswires & 310 & 658 & 497 & 4342 & 729 & 6536 \\
Thomson Reuters & 298 & 661 & 771 & 3786 & 1093 & 6609 \\
Total & 608 & 1319 & 1268 & 8128 & 1822 & 13145 \\
\hline
\end{tabular}

Note: Selected news are news that pass two filters: first, for each country the news item must include the name of the country plus any of the following keywords: crisis, debt, economy, deficit, default. For example, for Greece the first filter selects the news stories containing any of the terms: "greek crisis", "greek debt", "greek economy", "greek deficit", "greek default"; second, for each country, the news item must contain in it's title a country keyword. For example, for Greece the second filter selects the news that passed the first filter and that furthermore contain any of the following terms in the title: "greece", "greek", "greeks", "greece's", "hellas", "hellenic". The same applies to all five Euro-periphery countries. 
Table 4: Summary statistics for news and stock markets

\begin{tabular}{lcccc}
\hline \hline \multicolumn{1}{c}{ Variable } & Mean & Std. Dev. & Min. & Max. \\
\hline Negative & 0.032 & 0.016 & 0 & 0.136 \\
Positive & 0.007 & 0.007 & 0 & 0.062 \\
Pessimism & 0.024 & 0.018 & -0.046 & 0.136 \\
Portugal Return & 0 & 0.003 & -0.049 & 0.068 \\
Ireland Return & 0 & 0.003 & -0.031 & 0.04 \\
Italy Return & 0 & 0.004 & -0.061 & 0.046 \\
Greece Return & 0 & 0.006 & -0.079 & 0.072 \\
Spain Return & 0 & 0.004 & -0.041 & 0.098 \\
Germany Return & 0 & 0.003 & -0.043 & 0.039 \\
France Return & 0 & 0.003 & -0.039 & 0.037 \\
Austria Return & 0 & 0.003 & -0.056 & 0.062 \\
Finland Return & 0 & 0.003 & -0.05 & 0.04 \\
Belgium Return & 0 & 0.003 & -0.033 & 0.064 \\
UK Return & 0 & 0.003 & -0.034 & 0.029 \\
Switzerland Return & 0 & 0.002 & -0.03 & 0.04 \\
Norway Return & 0 & 0.003 & -0.034 & 0.048 \\
Brazil Return & 0 & 0.003 & -0.039 & 0.049 \\
Canada Return & 0 & 0.002 & -0.031 & 0.027 \\
US S\&P Return & 0 & 0.003 & -0.091 & 0.091 \\
US Dow Jones Return & 0 & 0.003 & -0.035 & 0.037 \\
Japan Return & 0 & 0.004 & -0.075 & 0.052 \\
China Return & 0 & 0.004 & -0.072 & 0.05 \\
\hline
\end{tabular}


Table 5: Portugal Stock Market - 30 minutes

\begin{tabular}{|c|c|c|c|c|c|}
\hline & $\begin{array}{c}(1) \\
\text { Return }_{t}\end{array}$ & $\begin{array}{c}(2) \\
\text { Return }\end{array}$ & $\begin{array}{c}(3) \\
\text { Return }_{t}\end{array}$ & $\begin{array}{c}(4) \\
\text { Return }\end{array}$ & $\begin{array}{c}(5) \\
\text { Return }_{t}\end{array}$ \\
\hline Return $_{t-1}$ & $\begin{array}{c}0.0532^{*} \\
(1.85)\end{array}$ & $\begin{array}{c}0.0523^{*} \\
(1.82)\end{array}$ & $\begin{array}{c}0.0527^{*} \\
(1.83)\end{array}$ & $\begin{array}{c}0.0526^{*} \\
(1.83)\end{array}$ & $\begin{array}{c}0.0523^{*} \\
(1.85)\end{array}$ \\
\hline Return $_{t-2}$ & $\begin{array}{c}0.0148 \\
(0.56)\end{array}$ & $\begin{array}{c}0.0154 \\
(0.59)\end{array}$ & $\begin{array}{c}0.0146 \\
(0.56)\end{array}$ & $\begin{array}{c}0.0153 \\
(0.58)\end{array}$ & $\begin{array}{c}0.0160 \\
(0.61)\end{array}$ \\
\hline $\operatorname{Return}_{t-3}$ & $\begin{array}{r}0.0157 \\
(0.48)\end{array}$ & $\begin{array}{c}0.0152 \\
(0.47)\end{array}$ & $\begin{array}{c}0.0156 \\
(0.48)\end{array}$ & $\begin{array}{c}0.0153 \\
(0.47)\end{array}$ & $\begin{array}{c}0.0149 \\
(0.46)\end{array}$ \\
\hline Return $_{t-4}$ & $\begin{array}{c}0.00767 \\
(0.26)\end{array}$ & $\begin{array}{c}0.00708 \\
(0.24)\end{array}$ & $\begin{array}{c}0.00660 \\
(0.22)\end{array}$ & $\begin{array}{c}0.00750 \\
(0.25)\end{array}$ & $\begin{array}{c}0.00854 \\
(0.29)\end{array}$ \\
\hline $\operatorname{Return}_{t-5}$ & $\begin{array}{c}0.0138 \\
(0.53)\end{array}$ & $\begin{array}{c}0.0140 \\
(0.54)\end{array}$ & $\begin{array}{c}0.0136 \\
(0.53)\end{array}$ & $\begin{array}{c}0.0136 \\
(0.53)\end{array}$ & $\begin{array}{c}0.0143 \\
(0.56)\end{array}$ \\
\hline Positive & $\begin{array}{c}0.0131^{*} \\
(1.71)\end{array}$ & & & & \\
\hline Negative & & $\begin{array}{c}-0.00768^{* * *} \\
(-2.61)\end{array}$ & & & \\
\hline Pessimism & & & $\begin{array}{c}-0.00812^{* * *} \\
(-2.99)\end{array}$ & & \\
\hline Average Pessimism & & & & $\begin{array}{c}-0.00531^{* *} \\
(-2.09)\end{array}$ & \\
\hline News Count & & & & & $\begin{array}{c}-0.0000111 \\
(-0.17)\end{array}$ \\
\hline Constant & $\begin{array}{c}-0.0000719 \\
(-1.01)\end{array}$ & $\begin{array}{c}0.000269^{* * *} \\
(2.64)\end{array}$ & $\begin{array}{c}0.000223^{* * *} \\
(2.74)\end{array}$ & $\begin{array}{c}0.000153^{* *} \\
(2.05)\end{array}$ & $\begin{array}{c}0.0000500 \\
(0.38)\end{array}$ \\
\hline Observations & 5255 & 5255 & 5255 & 5255 & 5255 \\
\hline Adjusted $R^{2}$ & 0.003 & 0.004 & 0.004 & 0.003 & 0.003 \\
\hline
\end{tabular}

$t$ statistics in parentheses

${ }^{*} \mathrm{p}<.1,{ }^{* *} \mathrm{p}<.05, * * * \mathrm{p}<.01$ 
Table 6: Ireland stock market - 30 minutes

\begin{tabular}{lccccc}
\multicolumn{6}{c}{ Table 6: Ireland stock market - 30 minutes } \\
& $(1)$ & $(2)$ & $(3)$ & $(4)$ & $(5)$ \\
& Return $_{t}$ & Return $_{t}$ & Return $_{t}$ & Return $_{t}$ & Return $_{t}$ \\
\hline Return $_{t-1}$ & $0.0580^{* *}$ & $0.0580^{* *}$ & $0.0575^{* *}$ & $0.0576^{* *}$ & $0.0585^{* *}$ \\
& $(1.99)$ & $(1.99)$ & $(1.98)$ & $(1.98)$ & $(2.01)$ \\
Return $_{t-2}$ & & & & 0.0350 & 0.0351 \\
& $(1.18)$ & $(1.19)$ & $(1.18)$ & $(1.19)$ & $(1.20)$ \\
Return $_{t-3}$ & -0.0420 & -0.0415 & -0.0419 & -0.0417 & -0.0415 \\
& $(-1.47)$ & $(-1.46)$ & $(-1.47)$ & $(-1.46)$ & $(-1.46)$ \\
Return $_{t-4}$ & 0.0179 & 0.0172 & 0.0176 & 0.0171 & 0.0175 \\
& $(0.75)$ & $(0.72)$ & $(0.74)$ & $(0.72)$ & $(0.73)$ \\
Return $_{t-5}$ & & & & \\
& $(1.02)$ & $(0.97)$ & $(0.97)$ & $(0.99)$ & $(1.03)$
\end{tabular}

Positive

0.00681

(0.99)

Negative

$-0.00664^{* *}$

$(-1.99)$

Pessimism

$-0.00645^{* *}$

$(-2.18)$

Average Pessimism

$-0.00443^{*}$

$(-1.73)$

News Count

0.00000326

(0.12)

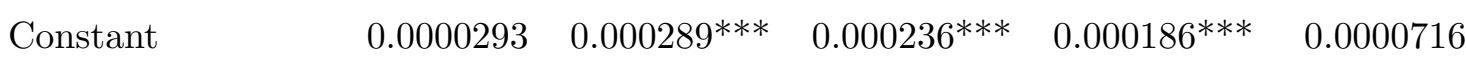

\begin{tabular}{lccccc} 
& $(0.42)$ & $(2.61)$ & $(2.89)$ & $(2.59)$ & $(1.10)$ \\
\hline Observations & 5080 & 5080 & 5080 & 5080 & 5080 \\
Adjusted $R^{2}$ & 0.004 & 0.005 & 0.005 & 0.005 & 0.004 \\
\hline \hline$t$ statistics in parentheses &
\end{tabular}

$* \mathrm{p}<.1,{ }^{* *} \mathrm{p}<.05, * * * \mathrm{p}<.01$ 
Table 7: Italy stock market - 30 minutes

\begin{tabular}{|c|c|c|c|c|c|}
\hline & $\begin{array}{c}(1) \\
\text { Return }_{t}\end{array}$ & $\begin{array}{c}(2) \\
\text { Return }_{t}\end{array}$ & $\begin{array}{c}(3) \\
\text { Return }\end{array}$ & $\begin{array}{c}(4) \\
\text { Return }_{t}\end{array}$ & $\begin{array}{c}(5) \\
\text { Return }\end{array}$ \\
\hline Return $_{t-1}$ & $\begin{array}{c}0.0304 \\
(0.92)\end{array}$ & $\begin{array}{c}0.0298 \\
(0.90)\end{array}$ & $\begin{array}{c}0.0298 \\
(0.90)\end{array}$ & $\begin{array}{c}0.0292 \\
(0.89)\end{array}$ & $\begin{array}{c}0.0302 \\
(0.92)\end{array}$ \\
\hline $\operatorname{Return}_{t-2}$ & $\begin{array}{c}0.0275 \\
(0.82)\end{array}$ & $\begin{array}{r}0.0287 \\
(0.86)\end{array}$ & $\begin{array}{c}0.0282 \\
(0.84)\end{array}$ & $\begin{array}{c}0.0286 \\
(0.86)\end{array}$ & $\begin{array}{c}0.0284 \\
(0.85)\end{array}$ \\
\hline Return $_{t-3}$ & $\begin{array}{c}-0.00170 \\
(-0.05)\end{array}$ & $\begin{array}{c}-0.00132 \\
(-0.04)\end{array}$ & $\begin{array}{c}-0.00142 \\
(-0.04)\end{array}$ & $\begin{array}{c}-0.00180 \\
(-0.05)\end{array}$ & $\begin{array}{c}-0.00147 \\
(-0.04)\end{array}$ \\
\hline Return $_{t-4}$ & $\begin{array}{c}-0.0410 \\
(-1.44)\end{array}$ & $\begin{array}{c}-0.0416 \\
(-1.46)\end{array}$ & $\begin{array}{c}-0.0420 \\
(-1.47)\end{array}$ & $\begin{array}{c}-0.0421 \\
(-1.48)\end{array}$ & $\begin{array}{c}-0.0406 \\
(-1.43)\end{array}$ \\
\hline $\operatorname{Return}_{t-5}$ & $\begin{array}{c}0.0131 \\
(0.49)\end{array}$ & $\begin{array}{c}0.0120 \\
(0.45)\end{array}$ & $\begin{array}{c}0.0117 \\
(0.44)\end{array}$ & $\begin{array}{c}0.0120 \\
(0.45)\end{array}$ & $\begin{array}{c}0.0132 \\
(0.50)\end{array}$ \\
\hline Positive & $\begin{array}{c}0.0169 \\
(1.50)\end{array}$ & & & & \\
\hline Negative & & $\begin{array}{c}-0.00784^{*} \\
(-1.72)\end{array}$ & & & \\
\hline Pessimism & & & $\begin{array}{c}-0.00886^{* *} \\
(-2.14)\end{array}$ & & \\
\hline Average Pessimism & & & & $\begin{array}{c}-0.0106^{* *} \\
(-2.49)\end{array}$ & \\
\hline News Count & & & & & $\begin{array}{c}-0.00000382 \\
(-0.10)\end{array}$ \\
\hline Constant & $\begin{array}{c}-0.0000551 \\
(-0.49)\end{array}$ & $\begin{array}{c}0.000319^{* *} \\
(1.99)\end{array}$ & $\begin{array}{c}0.000286^{* *} \\
(2.34)\end{array}$ & $\begin{array}{c}0.000327^{* * *} \\
(2.69)\end{array}$ & $\begin{array}{c}0.0000801 \\
(0.80)\end{array}$ \\
\hline Observations & 4865 & 4865 & 4865 & 4865 & 4865 \\
\hline Adjusted $R^{2}$ & 0.002 & 0.003 & 0.003 & 0.003 & 0.002 \\
\hline
\end{tabular}

$t$ statistics in parentheses

${ }^{*} \mathrm{p}<.1,{ }^{* *} \mathrm{p}<.05, * * * \mathrm{p}<.01$ 
Table 8: Greece stock market - 30 minutes

\begin{tabular}{|c|c|c|c|c|c|}
\hline & $\begin{array}{c}(1) \\
\text { Return }_{t}\end{array}$ & $\begin{array}{c}(2) \\
\text { Return }_{t}\end{array}$ & $\begin{array}{c}(3) \\
\text { Return }_{t}\end{array}$ & $\begin{array}{c}(4) \\
\text { Return }_{t}\end{array}$ & $\begin{array}{c}(5) \\
\text { Return }_{t}\end{array}$ \\
\hline $\operatorname{Return}_{t-1}$ & $\begin{array}{c}0.0706^{* *} \\
(2.24)\end{array}$ & $\begin{array}{c}0.0695^{* *} \\
(2.22)\end{array}$ & $\begin{array}{c}0.0690^{* *} \\
(2.20)\end{array}$ & $\begin{array}{c}0.0698^{* *} \\
(2.22)\end{array}$ & $\begin{array}{c}0.0725^{* *} \\
(2.30)\end{array}$ \\
\hline Return $_{t-2}$ & $\begin{array}{c}-0.0231 \\
(-0.82)\end{array}$ & $\begin{array}{c}-0.0225 \\
(-0.80)\end{array}$ & $\begin{array}{c}-0.0223 \\
(-0.79)\end{array}$ & $\begin{array}{c}-0.0228 \\
(-0.81)\end{array}$ & $\begin{array}{c}-0.0253 \\
(-0.89)\end{array}$ \\
\hline $\operatorname{Return}_{t-3}$ & $\begin{array}{c}0.0294 \\
(1.15)\end{array}$ & $\begin{array}{c}0.0291 \\
(1.14)\end{array}$ & $\begin{array}{c}0.0290 \\
(1.13)\end{array}$ & $\begin{array}{c}0.0291 \\
(1.13)\end{array}$ & $\begin{array}{c}0.0297 \\
(1.15)\end{array}$ \\
\hline Return $_{t-4}$ & $\begin{array}{c}-0.00105 \\
(-0.04)\end{array}$ & $\begin{array}{c}-0.00229 \\
(-0.09)\end{array}$ & $\begin{array}{c}-0.00270 \\
(-0.10)\end{array}$ & $\begin{array}{c}-0.00156 \\
(-0.06)\end{array}$ & $\begin{array}{c}0.00194 \\
(0.07)\end{array}$ \\
\hline $\operatorname{Return}_{t-5}$ & $\begin{array}{l}0.0193 \\
(1.01)\end{array}$ & $\begin{array}{c}0.0200 \\
(1.04)\end{array}$ & $\begin{array}{c}0.0200 \\
(1.04)\end{array}$ & $\begin{array}{c}0.0193 \\
(1.01)\end{array}$ & $\begin{array}{c}0.0184 \\
(0.96)\end{array}$ \\
\hline Positive & $\begin{array}{c}0.0296^{*} \\
(1.74)\end{array}$ & & & & \\
\hline Negative & & $\begin{array}{c}-0.0193^{* * *} \\
(-2.73)\end{array}$ & & & \\
\hline Pessimism & & & $\begin{array}{c}-0.0194^{* * *} \\
(-2.99)\end{array}$ & & \\
\hline Average Pessimism & & & & $\begin{array}{c}-0.0139 * * \\
(-2.17)\end{array}$ & \\
\hline News Count & & & & & $\begin{array}{c}0.0000579 \\
\quad(1.54)\end{array}$ \\
\hline Constant & $\begin{array}{c}-0.000160 \\
(-0.97)\end{array}$ & $\begin{array}{c}0.000678^{* * *} \\
(2.72)\end{array}$ & $\begin{array}{c}0.000536^{\text {*** }} \\
(2.75)\end{array}$ & $\begin{array}{c}0.000398^{* *} \\
(2.18)\end{array}$ & $\begin{array}{c}-0.000128 \\
(-0.98)\end{array}$ \\
\hline Observations & 3653 & 3653 & 3653 & 3653 & 3653 \\
\hline Adjusted $R^{2}$ & 0.002 & 0.003 & 0.004 & 0.002 & 0.004 \\
\hline
\end{tabular}


Table 9: Spain stock market - 30 minutes

\begin{tabular}{|c|c|c|c|c|c|}
\hline & $\begin{array}{c}(1) \\
\text { Return }_{t}\end{array}$ & $\begin{array}{c}(2) \\
\text { Return }_{t}\end{array}$ & $\begin{array}{c}(3) \\
\text { Return }_{t}\end{array}$ & $\begin{array}{c}(4) \\
\text { Return }_{t}\end{array}$ & $\begin{array}{c}(5) \\
\text { Return }_{t}\end{array}$ \\
\hline $\operatorname{Return}_{t-1}$ & $\begin{array}{l}0.0218 \\
(0.68)\end{array}$ & $\begin{array}{l}0.0215 \\
(0.67)\end{array}$ & $\begin{array}{c}0.0216 \\
(0.67)\end{array}$ & $\begin{array}{l}0.0218 \\
(0.68)\end{array}$ & $\begin{array}{c}0.0226 \\
(0.70)\end{array}$ \\
\hline Return $n_{t-2}$ & $\begin{array}{c}-0.0219 \\
(-0.71)\end{array}$ & $\begin{array}{c}-0.0214 \\
(-0.70)\end{array}$ & $\begin{array}{c}-0.0213 \\
(-0.70)\end{array}$ & $\begin{array}{c}-0.0219 \\
(-0.71)\end{array}$ & $\begin{array}{c}-0.0216 \\
(-0.70)\end{array}$ \\
\hline Return $_{t-3}$ & $\begin{array}{c}0.0171 \\
(0.58)\end{array}$ & $\begin{array}{c}0.0169 \\
(0.57)\end{array}$ & $\begin{array}{c}0.0165 \\
(0.56)\end{array}$ & $\begin{array}{c}0.0171 \\
(0.58)\end{array}$ & $\begin{array}{c}0.0176 \\
(0.59)\end{array}$ \\
\hline Return $_{t-4}$ & $\begin{array}{c}0.0517^{*} \\
(1.86)\end{array}$ & $\begin{array}{c}0.0518^{*} \\
(1.86)\end{array}$ & $\begin{array}{c}0.0520^{*} \\
(1.87)\end{array}$ & $\begin{array}{c}0.0517^{*} \\
(1.85)\end{array}$ & $\begin{array}{c}0.0517^{*} \\
(1.85)\end{array}$ \\
\hline Return $_{t-5}$ & $\begin{array}{c}-0.000743 \\
(-0.03)\end{array}$ & $\begin{array}{c}-0.00125 \\
(-0.05)\end{array}$ & $\begin{array}{c}-0.00129 \\
(-0.05)\end{array}$ & $\begin{array}{c}-0.000965 \\
(-0.04)\end{array}$ & $\begin{array}{c}-0.00155 \\
(-0.07)\end{array}$ \\
\hline Positive & $\begin{array}{c}0.0134 \\
(1.15)\end{array}$ & & & & \\
\hline Negative & & $\begin{array}{c}-0.00759^{*} \\
(-1.66)\end{array}$ & & & \\
\hline Pessimism & & & $\begin{array}{c}-0.00799^{*} \\
(-1.84)\end{array}$ & & \\
\hline Average Pessimism & & & & $\begin{array}{c}-0.00359 \\
(-0.77)\end{array}$ & \\
\hline News Count & & & & & $\begin{array}{c}-0.0000294 \\
(-0.91)\end{array}$ \\
\hline Constant & $\begin{array}{c}-0.0000930 \\
(-0.88)\end{array}$ & $\begin{array}{c}0.000250 \\
(1.52)\end{array}$ & $\begin{array}{c}0.000203 \\
(1.51)\end{array}$ & $\begin{array}{c}0.0000947 \\
(0.68)\end{array}$ & $\begin{array}{c}0.0000851 \\
(0.91)\end{array}$ \\
\hline Observations & 4357 & 4357 & 4357 & 4357 & 4357 \\
\hline Adjusted $R^{2}$ & 0.002 & 0.002 & 0.003 & 0.002 & 0.003 \\
\hline
\end{tabular}

$t$ statistics in parentheses

$* \mathrm{p}<.1,{ }^{* *} \mathrm{p}<.05, * * * \mathrm{p}<.01$ 
Table 10: Germany stock market - 30 minutes

\begin{tabular}{|c|c|c|c|c|c|}
\hline & $\begin{array}{c}\text { (1) } \\
\text { Return }_{t}\end{array}$ & $\begin{array}{c}(2) \\
\text { Return }_{t}\end{array}$ & $\begin{array}{c}(3) \\
\text { Return }_{t}\end{array}$ & $\begin{array}{c}(4) \\
\text { Return }_{t}\end{array}$ & $\begin{array}{c}(5) \\
\text { Return }_{t}\end{array}$ \\
\hline $\operatorname{Return}_{t-1}$ & $\begin{array}{c}0.0117 \\
(0.35)\end{array}$ & $\begin{array}{c}0.0108 \\
(0.32)\end{array}$ & $\begin{array}{c}0.0105 \\
(0.31)\end{array}$ & $\begin{array}{c}0.0106 \\
(0.32)\end{array}$ & $\begin{array}{c}0.0116 \\
(0.35)\end{array}$ \\
\hline Return $_{t-2}$ & $\begin{array}{c}0.00141 \\
(0.04)\end{array}$ & $\begin{array}{c}0.00158 \\
(0.05)\end{array}$ & $\begin{array}{c}0.00169 \\
(0.05)\end{array}$ & $\begin{array}{c}0.00194 \\
(0.06)\end{array}$ & $\begin{array}{c}0.00136 \\
(0.04)\end{array}$ \\
\hline $\operatorname{Return}_{t-3}$ & $\begin{array}{c}-0.00622 \\
(-0.18)\end{array}$ & $\begin{array}{c}-0.00591 \\
(-0.17)\end{array}$ & $\begin{array}{c}-0.00606 \\
(-0.18)\end{array}$ & $\begin{array}{c}-0.00618 \\
(-0.18)\end{array}$ & $\begin{array}{c}-0.00558 \\
(-0.16)\end{array}$ \\
\hline $\operatorname{Return}_{t-4}$ & $\begin{array}{c}-0.0429 \\
(-1.51)\end{array}$ & $\begin{array}{c}-0.0430 \\
(-1.52)\end{array}$ & $\begin{array}{c}-0.0437 \\
(-1.55)\end{array}$ & $\begin{array}{c}-0.0434 \\
(-1.54)\end{array}$ & $\begin{array}{c}-0.0420 \\
(-1.48)\end{array}$ \\
\hline $\operatorname{Return}_{t-5}$ & $\begin{array}{c}-0.00817 \\
(-0.33)\end{array}$ & $\begin{array}{c}-0.00739 \\
(-0.30)\end{array}$ & $\begin{array}{c}-0.00741 \\
(-0.30)\end{array}$ & $\begin{array}{c}-0.00740 \\
(-0.30)\end{array}$ & $\begin{array}{c}-0.00847 \\
(-0.34)\end{array}$ \\
\hline Positive & $\begin{array}{c}0.0147^{*} \\
(1.72)\end{array}$ & & & & \\
\hline Negative & & $\begin{array}{c}-0.00475 \\
(-1.23)\end{array}$ & & & \\
\hline Pessimism & & & $\begin{array}{c}-0.00596^{*} \\
(-1.70)\end{array}$ & & \\
\hline Average Pessimism & & & & $\begin{array}{c}-0.00609^{*} \\
(-1.82)\end{array}$ & \\
\hline News Count & & & & & $\begin{array}{c}0.0000197 \\
(0.58)\end{array}$ \\
\hline Constant & $\begin{array}{c}0.0000151 \\
(0.17)\end{array}$ & $\begin{array}{c}0.000276^{* *} \\
(2.17)\end{array}$ & $\begin{array}{c}0.000270^{* * *} \\
(2.84)\end{array}$ & $\begin{array}{c}0.000272^{* * *} \\
(2.99)\end{array}$ & $\begin{array}{c}0.0000745 \\
\quad(0.92)\end{array}$ \\
\hline Observations & 4864 & 4864 & 4864 & 4864 & 4864 \\
\hline Adjusted $R^{2}$ & 0.001 & 0.001 & 0.001 & 0.001 & 0.001 \\
\hline
\end{tabular}

$t$ statistics in parentheses

$* \mathrm{p}<.1,{ }^{* *} \mathrm{p}<.05, * * * \mathrm{p}<.01$ 
Table 11: France stock market - 30 minutes

\begin{tabular}{|c|c|c|c|c|c|}
\hline & $\begin{array}{c}(1) \\
\text { Return }\end{array}$ & $\begin{array}{c}(2) \\
\text { Return }_{t}\end{array}$ & $\begin{array}{c}(3) \\
\text { Return }_{t}\end{array}$ & $\begin{array}{c}(4) \\
\text { Return }_{t}\end{array}$ & $\begin{array}{c}(5) \\
\text { Return }_{t}\end{array}$ \\
\hline Return $_{t-1}$ & $\begin{array}{l}0.0117 \\
(0.15)\end{array}$ & $\begin{array}{c}0.00662 \\
(0.09)\end{array}$ & $\begin{array}{c}0.00552 \\
(0.07)\end{array}$ & $\begin{array}{c}0.00568 \\
(0.08)\end{array}$ & $\begin{array}{c}0.0182 \\
(0.24)\end{array}$ \\
\hline Return $_{t-2}$ & $\begin{array}{c}-0.0142 \\
(-0.16)\end{array}$ & $\begin{array}{c}-0.0178 \\
(-0.20)\end{array}$ & $\begin{array}{c}-0.0153 \\
(-0.17)\end{array}$ & $\begin{array}{c}-0.0129 \\
(-0.14)\end{array}$ & $\begin{array}{r}-0.0217 \\
(-0.24)\end{array}$ \\
\hline Return $_{t-3}$ & $\begin{array}{c}0.0809 \\
(0.74)\end{array}$ & $\begin{array}{c}0.0784 \\
(0.72)\end{array}$ & $\begin{array}{r}0.0777 \\
(0.71)\end{array}$ & $\begin{array}{c}0.0775 \\
(0.71)\end{array}$ & $\begin{array}{c}0.0864 \\
(0.80)\end{array}$ \\
\hline Return $_{t-4}$ & $\begin{array}{c}-0.0796 \\
(-0.69)\end{array}$ & $\begin{array}{c}-0.0578 \\
(-0.49)\end{array}$ & $\begin{array}{c}-0.0623 \\
(-0.53)\end{array}$ & $\begin{array}{c}-0.0670 \\
(-0.57)\end{array}$ & $\begin{array}{c}-0.0836 \\
(-0.73)\end{array}$ \\
\hline $\operatorname{Return}_{t-5}$ & $\begin{array}{c}0.00263 \\
(0.02)\end{array}$ & $\begin{array}{c}-0.00790 \\
(-0.07)\end{array}$ & $\begin{array}{c}-0.00437 \\
(-0.04)\end{array}$ & $\begin{array}{c}-0.00189 \\
(-0.02)\end{array}$ & $\begin{array}{c}0.00193 \\
(0.02)\end{array}$ \\
\hline Positive & $\begin{array}{c}0.0264 \\
(1.47)\end{array}$ & & & & \\
\hline Negative & & $\begin{array}{c}-0.0260^{* * *} \\
(-2.63)\end{array}$ & & & \\
\hline Pessimism & & & $\begin{array}{c}-0.0242^{* * *} \\
(-2.91)\end{array}$ & & \\
\hline Average Pessimism & & & & $\begin{array}{c}-0.0185^{* *} \\
(-2.38)\end{array}$ & \\
\hline News Count & & & & & $\begin{array}{c}-0.000166 \\
(-1.38)\end{array}$ \\
\hline Constant & $\begin{array}{c}-0.0112 \\
(-0.79)\end{array}$ & $\begin{array}{c}-0.0117 \\
(-0.84)\end{array}$ & $\begin{array}{c}-0.0103 \\
(-0.75)\end{array}$ & $\begin{array}{c}-0.0110 \\
(-0.79)\end{array}$ & $\begin{array}{c}-0.0102 \\
(-0.76)\end{array}$ \\
\hline Observations & 830 & 830 & 830 & 830 & 830 \\
\hline Adjusted $R^{2}$ & -0.002 & 0.005 & 0.006 & 0.001 & 0.007 \\
\hline
\end{tabular}


Table 12: Austria stock market - 30 minutes

\begin{tabular}{|c|c|c|c|c|c|}
\hline & $\begin{array}{c}(1) \\
\text { Return }_{t}\end{array}$ & $\begin{array}{c}(2) \\
\text { Return }_{t}\end{array}$ & $\begin{array}{c}(3) \\
\text { Return }_{t}\end{array}$ & $\begin{array}{c}(4) \\
\text { Return }_{t}\end{array}$ & $\begin{array}{c}(5) \\
\text { Return }\end{array}$ \\
\hline $\operatorname{Return}_{t-1}$ & $\begin{array}{c}0.103^{* * *} \\
(2.83)\end{array}$ & $\begin{array}{c}0.102^{* * *} \\
(2.78)\end{array}$ & $\begin{array}{c}0.102^{* * *} \\
(2.79)\end{array}$ & $\begin{array}{c}0.102^{* * *} \\
(2.80)\end{array}$ & $\begin{array}{c}0.103^{* * *} \\
(2.82)\end{array}$ \\
\hline Return $_{t-2}$ & $\begin{array}{c}0.0229 \\
(0.61)\end{array}$ & $\begin{array}{c}0.0237 \\
(0.63)\end{array}$ & $\begin{array}{c}0.0237 \\
(0.63)\end{array}$ & $\begin{array}{c}0.0230 \\
(0.61)\end{array}$ & $\begin{array}{c}0.0238 \\
(0.64)\end{array}$ \\
\hline $\operatorname{Return}_{t-3}$ & $\begin{array}{c}0.0282 \\
(0.74)\end{array}$ & $\begin{array}{c}0.0268 \\
(0.71)\end{array}$ & $\begin{array}{c}0.0266 \\
(0.70)\end{array}$ & $\begin{array}{c}0.0279 \\
(0.74)\end{array}$ & $\begin{array}{c}0.0279 \\
(0.74)\end{array}$ \\
\hline Return $_{t-4}$ & $\begin{array}{c}-0.0104 \\
(-0.28)\end{array}$ & $\begin{array}{c}-0.00969 \\
(-0.26)\end{array}$ & $\begin{array}{c}-0.0106 \\
(-0.29)\end{array}$ & $\begin{array}{c}-0.0103 \\
(-0.28)\end{array}$ & $\begin{array}{c}-0.00899 \\
(-0.24)\end{array}$ \\
\hline $\operatorname{Return}_{t-5}$ & $\begin{array}{c}0.0571^{* *} \\
(2.54)\end{array}$ & $\begin{array}{c}0.0575^{* *} \\
(2.55)\end{array}$ & $\begin{array}{c}0.0571^{* *} \\
(2.53)\end{array}$ & $\begin{array}{c}0.0578^{* *} \\
(2.57)\end{array}$ & $\begin{array}{c}0.0577^{* *} \\
(2.57)\end{array}$ \\
\hline Positive & $\begin{array}{c}0.0190^{* *} \\
(2.06)\end{array}$ & & & & \\
\hline Negative & & $\begin{array}{c}-0.00984^{* * *} \\
(-2.82)\end{array}$ & & & \\
\hline Pessimism & & & $\begin{array}{c}-0.0106^{* * *} \\
(-3.21)\end{array}$ & & \\
\hline Average Pessimism & & & & $\begin{array}{c}-0.00593^{*} \\
(-1.92)\end{array}$ & \\
\hline News Count & & & & & $\begin{array}{c}-0.0000252 \\
(-0.63)\end{array}$ \\
\hline Constant & $\begin{array}{c}-0.0000696 \\
(-0.80)\end{array}$ & $\begin{array}{c}0.000385^{* * *} \\
(3.25)\end{array}$ & $\begin{array}{c}0.000330^{* * *} \\
(3.45)\end{array}$ & $\begin{array}{c}0.000216^{* *} \\
(2.42)\end{array}$ & $\begin{array}{c}0.000139 \\
(1.43)\end{array}$ \\
\hline Observations & 4654 & 4654 & 4654 & 4654 & 4654 \\
\hline Adjusted $R^{2}$ & 0.012 & 0.012 & 0.013 & 0.011 & 0.012 \\
\hline
\end{tabular}


Table 13: Belgium stock market - 30 minutes

\begin{tabular}{|c|c|c|c|c|c|}
\hline & $\begin{array}{c}(1) \\
\text { Return }_{t}\end{array}$ & $\begin{array}{c}(2) \\
\text { Return }_{t}\end{array}$ & $\begin{array}{c}(3) \\
\text { Return }_{t}\end{array}$ & $\begin{array}{c}(4) \\
\text { Return }_{t}\end{array}$ & $\begin{array}{c}(5) \\
\text { Return } \\
\end{array}$ \\
\hline $\operatorname{Return}_{t-1}$ & $\begin{array}{c}0.00581 \\
(0.19)\end{array}$ & $\begin{array}{c}0.00402 \\
(0.13)\end{array}$ & $\begin{array}{c}0.00461 \\
(0.15)\end{array}$ & $\begin{array}{c}0.00462 \\
(0.15)\end{array}$ & $\begin{array}{c}0.00468 \\
(0.15)\end{array}$ \\
\hline $\operatorname{Return}_{t-2}$ & $\begin{array}{c}-0.0349 \\
(-1.22)\end{array}$ & $\begin{array}{c}-0.0348 \\
(-1.22)\end{array}$ & $\begin{array}{c}-0.0351 \\
(-1.23)\end{array}$ & $\begin{array}{c}-0.0347 \\
(-1.22)\end{array}$ & $\begin{array}{c}-0.0345 \\
(-1.22)\end{array}$ \\
\hline $\operatorname{Return}_{t-3}$ & $\begin{array}{c}0.0469^{*} \\
(1.75)\end{array}$ & $\begin{array}{c}0.0465^{*} \\
(1.73)\end{array}$ & $\begin{array}{c}0.0465^{*} \\
(1.73)\end{array}$ & $\begin{array}{c}0.0467^{*} \\
(1.74)\end{array}$ & $\begin{array}{c}0.0468^{*} \\
(1.75)\end{array}$ \\
\hline Return $_{t-4}$ & $\begin{array}{c}0.0479 \\
(1.59)\end{array}$ & $\begin{array}{c}0.0488 \\
(1.61)\end{array}$ & $\begin{array}{c}0.0483 \\
(1.60)\end{array}$ & $\begin{array}{c}0.0485 \\
(1.60)\end{array}$ & $\begin{array}{c}0.0489 * \\
(1.65)\end{array}$ \\
\hline Return $_{t-5}$ & $\begin{array}{c}-0.0132 \\
(-0.42)\end{array}$ & $\begin{array}{c}-0.0129 \\
(-0.41)\end{array}$ & $\begin{array}{c}-0.0135 \\
(-0.43)\end{array}$ & $\begin{array}{c}-0.0129 \\
(-0.41)\end{array}$ & $\begin{array}{c}-0.0123 \\
(-0.39)\end{array}$ \\
\hline Positive & $\begin{array}{c}0.0124^{*} \\
(1.72)\end{array}$ & & & & \\
\hline Negative & & $\begin{array}{c}-0.00664^{* *} \\
(-2.24)\end{array}$ & & & \\
\hline Pessimism & & & $\begin{array}{c}-0.00714^{* *} \\
(-2.56)\end{array}$ & & \\
\hline Average Pessimism & & & & $\begin{array}{c}-0.00397 \\
(-1.57)\end{array}$ & \\
\hline News Count & & & & & $\begin{array}{c}-0.00000134 \\
(-0.03)\end{array}$ \\
\hline Constant & $\begin{array}{c}-0.0000693 \\
(-1.00)\end{array}$ & $\begin{array}{c}0.000233^{* *} \\
(2.29)\end{array}$ & $\begin{array}{c}0.000196 * * \\
(2.43)\end{array}$ & $\begin{array}{c}0.000119 \\
(1.63)\end{array}$ & $\begin{array}{c}0.0000259 \\
(0.31)\end{array}$ \\
\hline Observations & 5131 & 5131 & 5131 & 5131 & 5131 \\
\hline Adjusted $R^{2}$ & 0.004 & 0.005 & 0.005 & 0.004 & 0.004 \\
\hline
\end{tabular}

$t$ statistics in parentheses

$* \mathrm{p}<.1, * * \mathrm{p}<.05, * * * \mathrm{p}<.01$ 
Table 14: Finland stock market - 30 minutes

\begin{tabular}{|c|c|c|c|c|c|}
\hline & $\begin{array}{c}(1) \\
\text { Return }_{t}\end{array}$ & $\begin{array}{c}(2) \\
\text { Return }_{t}\end{array}$ & $\begin{array}{c}(3) \\
\text { Return }_{t}\end{array}$ & $\begin{array}{c}(4) \\
\text { Return }\end{array}$ & $\begin{array}{c}(5) \\
\text { Return }\end{array}$ \\
\hline Return $_{t-1}$ & $\begin{array}{c}0.0926^{* *} \\
(2.23)\end{array}$ & $\begin{array}{c}0.0914^{* *} \\
(2.20)\end{array}$ & $\begin{array}{c}0.0915^{* *} \\
(2.21)\end{array}$ & $\begin{array}{c}0.0921^{* *} \\
(2.21)\end{array}$ & $\begin{array}{c}0.0930^{* *} \\
(2.26)\end{array}$ \\
\hline Return $_{t-2}$ & $\begin{array}{c}0.0807^{*} \\
(1.89)\end{array}$ & $\begin{array}{c}0.0813^{*} \\
(1.91)\end{array}$ & $\begin{array}{c}0.0807^{*} \\
(1.89)\end{array}$ & $\begin{array}{c}0.0807^{*} \\
(1.89)\end{array}$ & $\begin{array}{c}0.0808^{*} \\
(1.92)\end{array}$ \\
\hline Return $_{t-3}$ & $\begin{array}{c}0.0330 \\
(1.11)\end{array}$ & $\begin{array}{c}0.0325 \\
(1.09)\end{array}$ & $\begin{array}{c}0.0322 \\
(1.08)\end{array}$ & $\begin{array}{c}0.0328 \\
(1.10)\end{array}$ & $\begin{array}{c}0.0333 \\
(1.12)\end{array}$ \\
\hline $\operatorname{Return}_{t-4}$ & $\begin{array}{c}-0.0363 \\
(-1.24)\end{array}$ & $\begin{array}{c}-0.0360 \\
(-1.23)\end{array}$ & $\begin{array}{c}-0.0361 \\
(-1.23)\end{array}$ & $\begin{array}{c}-0.0359 \\
(-1.23)\end{array}$ & $\begin{array}{c}-0.0361 \\
(-1.23)\end{array}$ \\
\hline $\operatorname{Return}_{t-5}$ & $\begin{array}{c}0.00645 \\
(0.23)\end{array}$ & $\begin{array}{c}0.00627 \\
(0.22)\end{array}$ & $\begin{array}{c}0.00608 \\
(0.21)\end{array}$ & $\begin{array}{c}0.00617 \\
(0.22)\end{array}$ & $\begin{array}{c}0.00640 \\
(0.23)\end{array}$ \\
\hline Positive & $\begin{array}{c}0.00860 \\
(0.96)\end{array}$ & & & & \\
\hline Negative & & $\begin{array}{c}-0.00780^{* *} \\
(-2.09)\end{array}$ & & & \\
\hline Pessimism & & & $\begin{array}{c}-0.00755^{* *} \\
(-2.24)\end{array}$ & & \\
\hline Average Pessimism & & & & $\begin{array}{c}-0.00527 \\
(-1.61)\end{array}$ & \\
\hline News Count & & & & & $\begin{array}{c}-0.00000673 \\
(-0.22)\end{array}$ \\
\hline Constant & $\begin{array}{c}0.0000331 \\
(0.35) \\
\end{array}$ & $\begin{array}{c}0.000346^{* * *} \\
(2.65)\end{array}$ & $\begin{array}{c}0.000281^{* * *} \\
(2.87)\end{array}$ & $\begin{array}{c}0.000225^{* *} \\
(2.38)\end{array}$ & $\begin{array}{c}0.000117 \\
(1.47)\end{array}$ \\
\hline Observations & 4387 & 4387 & 4387 & 4387 & 4387 \\
\hline Adjusted $R^{2}$ & 0.013 & 0.014 & 0.014 & 0.013 & 0.013 \\
\hline
\end{tabular}


Table 15: UK stock market - 30 minutes

\begin{tabular}{|c|c|c|c|c|c|}
\hline & $\begin{array}{c}(1) \\
\text { Return }_{t}\end{array}$ & $\begin{array}{c}(2) \\
\text { Return }_{t}\end{array}$ & $\begin{array}{c}(3) \\
\text { Return }_{t}\end{array}$ & $\begin{array}{c}(4) \\
\text { Return }_{t}\end{array}$ & $\begin{array}{c}(5) \\
\text { Return }_{t}\end{array}$ \\
\hline $\operatorname{Return}_{t-1}$ & $\begin{array}{c}-0.0313 \\
(-1.02)\end{array}$ & $\begin{array}{c}-0.0317 \\
(-1.04)\end{array}$ & $\begin{array}{c}-0.0318 \\
(-1.04)\end{array}$ & $\begin{array}{c}-0.0322 \\
(-1.05)\end{array}$ & $\begin{array}{c}-0.0309 \\
(-1.00)\end{array}$ \\
\hline Return $_{t-2}$ & $\begin{array}{c}0.0190 \\
(0.62)\end{array}$ & $\begin{array}{c}0.0191 \\
(0.62)\end{array}$ & $\begin{array}{c}0.0186 \\
(0.61)\end{array}$ & $\begin{array}{c}0.0195 \\
(0.63)\end{array}$ & $\begin{array}{c}0.0196 \\
(0.64)\end{array}$ \\
\hline $\operatorname{Return}_{t-3}$ & $\begin{array}{c}0.00116 \\
(0.04)\end{array}$ & $\begin{array}{c}0.000376 \\
(0.01)\end{array}$ & $\begin{array}{c}0.000434 \\
(0.01)\end{array}$ & $\begin{array}{l}0.000782 \\
\quad(0.02)\end{array}$ & $\begin{array}{c}0.00134 \\
(0.04)\end{array}$ \\
\hline Return $_{t-4}$ & $\begin{array}{c}0.0225 \\
(0.73)\end{array}$ & $\begin{array}{c}0.0230 \\
(0.74)\end{array}$ & $\begin{array}{c}0.0226 \\
(0.73)\end{array}$ & $\begin{array}{c}0.0223 \\
(0.72)\end{array}$ & $\begin{array}{c}0.0228 \\
(0.74)\end{array}$ \\
\hline $\operatorname{Return}_{t-5}$ & $\begin{array}{c}0.0166 \\
(0.59)\end{array}$ & $\begin{array}{c}0.0162 \\
(0.57)\end{array}$ & $\begin{array}{c}0.0162 \\
(0.57)\end{array}$ & $\begin{array}{c}0.0160 \\
(0.57)\end{array}$ & $\begin{array}{c}0.0169 \\
(0.60)\end{array}$ \\
\hline Positive & $\begin{array}{c}0.00951 \\
(1.53)\end{array}$ & & & & \\
\hline Negative & & $\begin{array}{c}-0.00593^{* *} \\
(-2.17)\end{array}$ & & & \\
\hline Pessimism & & & $\begin{array}{c}-0.00618^{* *} \\
(-2.51)\end{array}$ & & \\
\hline Average Pessimism & & & & $\begin{array}{c}-0.00455^{*} \\
(-1.81)\end{array}$ & \\
\hline News Count & & & & & $\begin{array}{l}0.0000130 \\
\quad(0.53)\end{array}$ \\
\hline Constant & $\begin{array}{c}-0.0000423 \\
(-0.63)\end{array}$ & $\begin{array}{c}0.000216^{* *} \\
(2.33)\end{array}$ & $\begin{array}{c}0.000179^{* * *} \\
(2.58)\end{array}$ & $\begin{array}{c}0.000138^{* *} \\
(2.00)\end{array}$ & $\begin{array}{c}-0.00000365 \\
(-0.06)\end{array}$ \\
\hline Observations & 5119 & 5119 & 5119 & 5119 & 5119 \\
\hline Adjusted $R^{2}$ & 0.001 & 0.001 & 0.001 & 0.001 & 0.000 \\
\hline
\end{tabular}


Table 16: Switzerland stock market - 30 minutes

\begin{tabular}{|c|c|c|c|c|c|}
\hline & $\begin{array}{c}(1) \\
\text { Return }_{t}\end{array}$ & $\begin{array}{c}(2) \\
\text { Return }_{t}\end{array}$ & $\begin{array}{c}(3) \\
\text { Return }_{t}\end{array}$ & $\begin{array}{c}(4) \\
\text { Return }_{t}\end{array}$ & $\begin{array}{c}(5) \\
\text { Return }_{t}\end{array}$ \\
\hline Return $n_{t-1}$ & $\begin{array}{c}0.00918 \\
(0.22)\end{array}$ & $\begin{array}{c}0.00876 \\
(0.21)\end{array}$ & $\begin{array}{c}0.00906 \\
(0.22)\end{array}$ & $\begin{array}{c}0.00862 \\
(0.21)\end{array}$ & $\begin{array}{c}0.00851 \\
(0.20)\end{array}$ \\
\hline Return $_{t-2}$ & $\begin{array}{r}-0.0277 \\
(-0.74)\end{array}$ & $\begin{array}{c}-0.0275 \\
(-0.74)\end{array}$ & $\begin{array}{c}-0.0280 \\
(-0.75)\end{array}$ & $\begin{array}{c}-0.0273 \\
(-0.73)\end{array}$ & $\begin{array}{c}-0.0270 \\
(-0.72)\end{array}$ \\
\hline Return $_{t-3}$ & $\begin{array}{c}0.0533 \\
(1.48)\end{array}$ & $\begin{array}{c}0.0530 \\
(1.47)\end{array}$ & $\begin{array}{c}0.0528 \\
(1.46)\end{array}$ & $\begin{array}{c}0.0530 \\
(1.47)\end{array}$ & $\begin{array}{c}0.0536 \\
(1.48)\end{array}$ \\
\hline Return $_{t-4}$ & $\begin{array}{c}-0.0783^{* *} \\
(-2.02)\end{array}$ & $\begin{array}{c}-0.0789^{* *} \\
(-2.04)\end{array}$ & $\begin{array}{c}-0.0790^{* *} \\
(-2.04)\end{array}$ & $\begin{array}{c}-0.0789^{* *} \\
(-2.04)\end{array}$ & $\begin{array}{c}-0.0784^{* *} \\
(-2.03)\end{array}$ \\
\hline Return $_{t-5}$ & $\begin{array}{c}0.00853 \\
(0.33)\end{array}$ & $\begin{array}{c}0.00812 \\
(0.32)\end{array}$ & $\begin{array}{c}0.00771 \\
(0.30)\end{array}$ & $\begin{array}{c}0.00872 \\
(0.34)\end{array}$ & $\begin{array}{c}0.00912 \\
(0.35)\end{array}$ \\
\hline Positive & $\begin{array}{c}0.00927 \\
(1.32)\end{array}$ & & & & \\
\hline Negative & & $\begin{array}{c}-0.00499^{*} \\
(-1.86)\end{array}$ & & & \\
\hline Pessimism & & & $\begin{array}{c}-0.00536^{* *} \\
(-2.15)\end{array}$ & & \\
\hline Average Pessimism & & & & $\begin{array}{c}-0.00332 \\
(-1.41)\end{array}$ & \\
\hline News Count & & & & & $\begin{array}{c}-0.00000604 \\
(-0.23)\end{array}$ \\
\hline Constant & $\begin{array}{c}-0.0000396 \\
(-0.58)\end{array}$ & $\begin{array}{c}0.000190^{* *} \\
(2.12)\end{array}$ & $\begin{array}{c}0.000161^{* *} \\
(2.31)\end{array}$ & $\begin{array}{c}0.000110^{*} \\
(1.70)\end{array}$ & $\begin{array}{c}0.0000462 \\
(0.74)\end{array}$ \\
\hline Observations & 4706 & 4706 & 4706 & 4706 & 4706 \\
\hline Adjusted $R^{2}$ & 0.003 & 0.003 & 0.003 & 0.003 & 0.002 \\
\hline
\end{tabular}


Table 17: Norway stock market - 30 minutes

\begin{tabular}{|c|c|c|c|c|c|}
\hline & $\begin{array}{c}(1) \\
\text { Return }_{t}\end{array}$ & $\begin{array}{c}(2) \\
\text { Return }_{t}\end{array}$ & $\begin{array}{c}(3) \\
\text { Return }_{t}\end{array}$ & $\begin{array}{c}(4) \\
\text { Return }\end{array}$ & $\begin{array}{c}(5) \\
\text { Return }\end{array}$ \\
\hline $\operatorname{Return}_{t-1}$ & $\begin{array}{l}0.0292 \\
(0.77)\end{array}$ & $\begin{array}{l}0.0280 \\
(0.74)\end{array}$ & $\begin{array}{l}0.0278 \\
(0.73)\end{array}$ & $\begin{array}{c}0.0279 \\
(0.74)\end{array}$ & $\begin{array}{l}0.0291 \\
(0.76)\end{array}$ \\
\hline $\operatorname{Return}_{t-2}$ & $\begin{array}{c}0.0396 \\
(1.01)\end{array}$ & $\begin{array}{c}0.0415 \\
(1.05)\end{array}$ & $\begin{array}{c}0.0415 \\
(1.05)\end{array}$ & $\begin{array}{c}0.0412 \\
(1.05)\end{array}$ & $\begin{array}{c}0.0402 \\
(1.02)\end{array}$ \\
\hline $\operatorname{Return}_{t-3}$ & $\begin{array}{c}0.000992 \\
(0.03)\end{array}$ & $\begin{array}{c}0.000776 \\
(0.02)\end{array}$ & $\begin{array}{c}0.000404 \\
(0.01)\end{array}$ & $\begin{array}{c}0.000759 \\
(0.02)\end{array}$ & $\begin{array}{c}0.00152 \\
(0.04)\end{array}$ \\
\hline $\operatorname{Return}_{t-4}$ & $\begin{array}{c}-0.0746^{* *} \\
(-2.15)\end{array}$ & $\begin{array}{c}-0.0745^{* *} \\
(-2.15)\end{array}$ & $\begin{array}{c}-0.0749^{* *} \\
(-2.16)\end{array}$ & $\begin{array}{c}-0.0748^{* *} \\
(-2.16)\end{array}$ & $\begin{array}{c}-0.0739^{* *} \\
(-2.14)\end{array}$ \\
\hline $\operatorname{Return}_{t-5}$ & $\begin{array}{c}0.0182 \\
(0.64)\end{array}$ & $\begin{array}{c}0.0189 \\
(0.67)\end{array}$ & $\begin{array}{c}0.0182 \\
(0.64)\end{array}$ & $\begin{array}{c}0.0191 \\
(0.67)\end{array}$ & $\begin{array}{c}0.0196 \\
(0.69)\end{array}$ \\
\hline Positive & $\begin{array}{c}0.0202^{* *} \\
(2.03)\end{array}$ & & & & \\
\hline Negative & & $\begin{array}{c}-0.00669 \\
(-1.64)\end{array}$ & & & \\
\hline Pessimism & & & $\begin{array}{c}-0.00827^{* *} \\
(-2.16)\end{array}$ & & \\
\hline Average Pessimism & & & & $\begin{array}{c}-0.00602^{*} \\
(-1.69)\end{array}$ & \\
\hline News Count & & & & & $\begin{array}{c}0.00000664 \\
(0.22)\end{array}$ \\
\hline Constant & $\begin{array}{c}-0.0000528 \\
(-0.54)\end{array}$ & $\begin{array}{c}0.000311^{* *} \\
(2.27)\end{array}$ & $\begin{array}{c}0.000299^{* * *} \\
(2.82)\end{array}$ & $\begin{array}{c}0.000243^{* *} \\
(2.45)\end{array}$ & $\begin{array}{c}0.0000795 \\
\quad(0.97)\end{array}$ \\
\hline Observations & 4412 & 4412 & 4412 & 4412 & 4412 \\
\hline Adjusted $R^{2}$ & 0.006 & 0.005 & 0.006 & 0.005 & 0.005 \\
\hline
\end{tabular}

$t$ statistics in parentheses

$* \mathrm{p}<.1, * * \mathrm{p}<.05, * * * \mathrm{p}<.01$ 
Table 18: Brazil stock market - 30 minutes

\begin{tabular}{|c|c|c|c|c|c|}
\hline & $\begin{array}{c}(1) \\
\text { Return }_{t}\end{array}$ & $\begin{array}{c}(2) \\
\text { Return }\end{array}$ & $\begin{array}{c}(3) \\
\text { Return }_{t}\end{array}$ & $\begin{array}{c}(4) \\
\text { Return }\end{array}$ & $\begin{array}{c}(5) \\
\text { Return }_{t}\end{array}$ \\
\hline $\operatorname{Return}_{t-1}$ & $\begin{array}{c}-0.0182 \\
(-0.53)\end{array}$ & $\begin{array}{c}-0.0185 \\
(-0.53)\end{array}$ & $\begin{array}{c}-0.0193 \\
(-0.56)\end{array}$ & $\begin{array}{c}-0.0187 \\
(-0.54)\end{array}$ & $\begin{array}{c}-0.0176 \\
(-0.51)\end{array}$ \\
\hline $\operatorname{Return}_{t-2}$ & $\begin{array}{c}-0.00979 \\
(-0.26)\end{array}$ & $\begin{array}{c}-0.00873 \\
(-0.23)\end{array}$ & $\begin{array}{c}-0.00866 \\
(-0.23)\end{array}$ & $\begin{array}{c}-0.00921 \\
(-0.25)\end{array}$ & $\begin{array}{c}-0.00986 \\
(-0.26)\end{array}$ \\
\hline Return $_{t-3}$ & $\begin{array}{c}0.0239 \\
(0.80)\end{array}$ & $\begin{array}{c}0.0234 \\
(0.78)\end{array}$ & $\begin{array}{c}0.0228 \\
(0.76)\end{array}$ & $\begin{array}{c}0.0233 \\
(0.78)\end{array}$ & $\begin{array}{c}0.0245 \\
(0.82)\end{array}$ \\
\hline Return $_{t-4}$ & $\begin{array}{c}-0.0544^{*} \\
(-1.91)\end{array}$ & $\begin{array}{c}-0.0527^{*} \\
(-1.84)\end{array}$ & $\begin{array}{c}-0.0527^{*} \\
(-1.84)\end{array}$ & $\begin{array}{c}-0.0535^{*} \\
(-1.87)\end{array}$ & $\begin{array}{c}-0.0529^{*} \\
(-1.86)\end{array}$ \\
\hline Return $_{t-5}$ & $\begin{array}{c}-0.00340 \\
(-0.16)\end{array}$ & $\begin{array}{c}-0.00428 \\
(-0.20)\end{array}$ & $\begin{array}{c}-0.00459 \\
(-0.22)\end{array}$ & $\begin{array}{c}-0.00437 \\
(-0.21)\end{array}$ & $\begin{array}{c}-0.00383 \\
(-0.18)\end{array}$ \\
\hline Positive & $\begin{array}{c}0.0193 \\
(1.47)\end{array}$ & & & & \\
\hline Negative & & $\begin{array}{c}-0.00805 \\
(-1.42)\end{array}$ & & & \\
\hline Pessimism & & & $\begin{array}{c}-0.00934^{*} \\
(-1.84)\end{array}$ & & \\
\hline Average Pessimism & & & & $\begin{array}{c}-0.00901^{*} \\
(-1.88)\end{array}$ & \\
\hline News Count & & & & & $\begin{array}{c}0.0000291 \\
(1.54)\end{array}$ \\
\hline Constant & $\begin{array}{c}-0.0000280 \\
(-0.21) \\
\end{array}$ & $\begin{array}{c}0.000369^{*} \\
(1.84) \\
\end{array}$ & $\begin{array}{c}0.000341^{* *} \\
(2.29)\end{array}$ & $\begin{array}{c}0.000337^{* * *} \\
(2.44)\end{array}$ & $\begin{array}{c}-0.00000343 \\
(-0.04) \\
\end{array}$ \\
\hline Observations & 3031 & 3031 & 3031 & 3031 & 3031 \\
\hline Adjusted $R^{2}$ & 0.001 & 0.001 & 0.001 & 0.001 & 0.002 \\
\hline
\end{tabular}


Table 19: Canada stock market - 30 minutes

\begin{tabular}{|c|c|c|c|c|c|}
\hline & $\begin{array}{c}(1) \\
\text { Return }\end{array}$ & $\begin{array}{c}(2) \\
\text { Return }_{t}\end{array}$ & $\begin{array}{c}(3) \\
\text { Return }_{t}\end{array}$ & $\begin{array}{c}(4) \\
\text { Return }\end{array}$ & $\begin{array}{c}(5) \\
\text { Return }_{t}\end{array}$ \\
\hline Return $_{t-1}$ & $\begin{array}{c}-0.0180 \\
(-0.47)\end{array}$ & $\begin{array}{c}-0.0162 \\
(-0.42)\end{array}$ & $\begin{array}{c}-0.0177 \\
(-0.46)\end{array}$ & $\begin{array}{c}-0.0188 \\
(-0.49)\end{array}$ & $\begin{array}{c}-0.0152 \\
(-0.40)\end{array}$ \\
\hline $\operatorname{Return}_{t-2}$ & $\begin{array}{c}-0.00375 \\
(-0.12)\end{array}$ & $\begin{array}{c}-0.00453 \\
(-0.14)\end{array}$ & $\begin{array}{c}-0.00391 \\
(-0.12)\end{array}$ & $\begin{array}{c}-0.00325 \\
(-0.10)\end{array}$ & $\begin{array}{c}-0.00518 \\
(-0.16)\end{array}$ \\
\hline Return $_{t-3}$ & $\begin{array}{c}0.0124 \\
(0.75)\end{array}$ & $\begin{array}{c}0.0116 \\
(0.71)\end{array}$ & $\begin{array}{c}0.0112 \\
(0.68)\end{array}$ & $\begin{array}{c}0.0111 \\
(0.67)\end{array}$ & $\begin{array}{c}0.0131 \\
(0.80)\end{array}$ \\
\hline $\operatorname{Return}_{t-4}$ & $\begin{array}{c}-0.00568 \\
(-0.31)\end{array}$ & $\begin{array}{c}-0.00473 \\
(-0.26)\end{array}$ & $\begin{array}{c}-0.00488 \\
(-0.27)\end{array}$ & $\begin{array}{c}-0.00621 \\
(-0.34)\end{array}$ & $\begin{array}{c}-0.00536 \\
(-0.29)\end{array}$ \\
\hline $\operatorname{Return}_{t-5}$ & $\begin{array}{c}0.0151 \\
(0.60)\end{array}$ & $\begin{array}{c}0.0146 \\
(0.59)\end{array}$ & $\begin{array}{c}0.0144 \\
(0.58)\end{array}$ & $\begin{array}{c}0.0153 \\
(0.62)\end{array}$ & $\begin{array}{c}0.0153 \\
(0.62)\end{array}$ \\
\hline Positive & $\begin{array}{c}0.0222^{* *} \\
(2.52)\end{array}$ & & & & \\
\hline Negative & & $\begin{array}{c}-0.00591 \\
(-1.64)\end{array}$ & & & \\
\hline Pessimism & & & $\begin{array}{c}-0.00785^{* *} \\
(-2.21)\end{array}$ & & \\
\hline Average Pessimism & & & & $\begin{array}{c}-0.0137 * * * \\
(-2.66)\end{array}$ & \\
\hline News Count & & & & & $\begin{array}{c}0.00000249 \\
(0.97)\end{array}$ \\
\hline Constant & $\begin{array}{c}-0.000207^{* *} \\
(-2.29)\end{array}$ & $\begin{array}{c}0.000148 \\
(1.22)\end{array}$ & $\begin{array}{c}0.000152 \\
(1.54)\end{array}$ & $\begin{array}{c}0.000300^{* *} \\
(2.25)\end{array}$ & $\begin{array}{c}-0.0000588 \\
(-0.77)\end{array}$ \\
\hline Observations & 1867 & 1867 & 1867 & 1867 & 1867 \\
\hline Adjusted $R^{2}$ & 0.001 & -0.001 & 0.000 & 0.003 & -0.002 \\
\hline
\end{tabular}


Table 20: US Dow Jones stock market - 30 minutes

\begin{tabular}{|c|c|c|c|c|c|}
\hline & $\begin{array}{c}(1) \\
\text { Return }\end{array}$ & $\begin{array}{c}(2) \\
\text { Return }_{t}\end{array}$ & $\begin{array}{c}(3) \\
\text { Return }_{t}\end{array}$ & $\begin{array}{c}(4) \\
\text { Return }_{t}\end{array}$ & $\begin{array}{c}(5) \\
\text { Return }\end{array}$ \\
\hline Return $_{t-1}$ & $\begin{array}{c}-0.161^{*} \\
(-1.68)\end{array}$ & $\begin{array}{c}-0.163^{*} \\
(-1.70)\end{array}$ & $\begin{array}{c}-0.163^{*} \\
(-1.71)\end{array}$ & $\begin{array}{c}-0.162^{*} \\
(-1.68)\end{array}$ & $\begin{array}{c}-0.163^{*} \\
(-1.70)\end{array}$ \\
\hline $\operatorname{Return}_{t-2}$ & $\begin{array}{c}0.0391 \\
(0.50)\end{array}$ & $\begin{array}{c}0.0432 \\
(0.55)\end{array}$ & $\begin{array}{c}0.0420 \\
(0.54)\end{array}$ & $\begin{array}{c}0.0394 \\
(0.50)\end{array}$ & $\begin{array}{c}0.0410 \\
(0.52)\end{array}$ \\
\hline $\operatorname{Return}_{t-3}$ & $\begin{array}{c}0.0132 \\
(0.22)\end{array}$ & $\begin{array}{c}0.00836 \\
(0.14)\end{array}$ & $\begin{array}{c}0.00978 \\
(0.16)\end{array}$ & $\begin{array}{r}0.0127 \\
(0.21)\end{array}$ & $\begin{array}{r}0.0127 \\
(0.21)\end{array}$ \\
\hline Return $_{t-4}$ & $\begin{array}{c}-0.0254 \\
(-0.46)\end{array}$ & $\begin{array}{c}-0.0236 \\
(-0.43)\end{array}$ & $\begin{array}{c}-0.0240 \\
(-0.44)\end{array}$ & $\begin{array}{c}-0.0253 \\
(-0.46)\end{array}$ & $\begin{array}{c}-0.0271 \\
(-0.49)\end{array}$ \\
\hline $\operatorname{Return}_{t-5}$ & $\begin{array}{c}0.0548 \\
(1.40)\end{array}$ & $\begin{array}{c}0.0536 \\
(1.37)\end{array}$ & $\begin{array}{c}0.0542 \\
(1.39)\end{array}$ & $\begin{array}{c}0.0546 \\
(1.40)\end{array}$ & $\begin{array}{c}0.0567 \\
(1.46)\end{array}$ \\
\hline Positive & $\begin{array}{c}0.00853 \\
(0.41)\end{array}$ & & & & \\
\hline Negative & & $\begin{array}{c}-0.0224^{* * *} \\
(-2.60)\end{array}$ & & & \\
\hline Pessimism & & & $\begin{array}{c}-0.0190^{* *} \\
(-2.40)\end{array}$ & & \\
\hline Average Pessimism & & & & $\begin{array}{c}-0.00587 \\
(-0.82)\end{array}$ & \\
\hline News Count & & & & & $\begin{array}{c}-0.0000119 \\
(-0.87)\end{array}$ \\
\hline Constant & $\begin{array}{c}-0.000101 \\
(-0.49)\end{array}$ & $\begin{array}{c}0.000691^{* *} \\
(2.23)\end{array}$ & $\begin{array}{c}0.000438^{*} \\
(1.83)\end{array}$ & $\begin{array}{c}0.000111 \\
(0.51)\end{array}$ & $\begin{array}{c}0.0000594 \\
(0.46)\end{array}$ \\
\hline Observations & 1529 & 1529 & 1529 & 1529 & 1529 \\
\hline Adjusted $R^{2}$ & 0.007 & 0.011 & 0.011 & 0.007 & 0.007 \\
\hline
\end{tabular}


Table 21: US S\&P 500 stock market - 30 minutes

\begin{tabular}{|c|c|c|c|c|c|}
\hline & $\begin{array}{c}(1) \\
\text { Return }_{t}\end{array}$ & $\begin{array}{c}(2) \\
\text { Return }_{t}\end{array}$ & $\begin{array}{c}(3) \\
\text { Return }_{t}\end{array}$ & $\begin{array}{c}(4) \\
\text { Return }_{t}\end{array}$ & $\begin{array}{c}(5) \\
\text { Return }\end{array}$ \\
\hline Return $_{t-1}$ & $\begin{array}{c}-0.0605^{* *} \\
(-2.03)\end{array}$ & $\begin{array}{c}-0.0590 * * \\
(-2.02)\end{array}$ & $\begin{array}{c}-0.0596^{* *} \\
(-2.03)\end{array}$ & $\begin{array}{c}-0.0594^{* *} \\
(-2.02)\end{array}$ & $\begin{array}{c}-0.0600^{* *} \\
(-2.01)\end{array}$ \\
\hline $\operatorname{Return}_{t-2}$ & $\begin{array}{c}-0.0142 \\
(-0.51)\end{array}$ & $\begin{array}{c}-0.0132 \\
(-0.47)\end{array}$ & $\begin{array}{r}-0.0127 \\
(-0.45)\end{array}$ & $\begin{array}{c}-0.0151 \\
(-0.54)\end{array}$ & $\begin{array}{c}-0.0151 \\
(-0.54)\end{array}$ \\
\hline $\operatorname{Return}_{t-3}$ & $\begin{array}{c}-0.0332 \\
(-0.84)\end{array}$ & $\begin{array}{c}-0.0357 \\
(-0.91)\end{array}$ & $\begin{array}{c}-0.0343 \\
(-0.87)\end{array}$ & $\begin{array}{c}-0.0346 \\
(-0.88)\end{array}$ & $\begin{array}{c}-0.0340 \\
(-0.87)\end{array}$ \\
\hline $\operatorname{Return}_{t-4}$ & $\begin{array}{c}-0.0224 \\
(-0.48)\end{array}$ & $\begin{array}{c}-0.0228 \\
(-0.49)\end{array}$ & $\begin{array}{c}-0.0219 \\
(-0.47)\end{array}$ & $\begin{array}{c}-0.0220 \\
(-0.47)\end{array}$ & $\begin{array}{c}-0.0232 \\
(-0.49)\end{array}$ \\
\hline $\operatorname{Return}_{t-5}$ & $\begin{array}{c}-0.0353 \\
(-0.79)\end{array}$ & $\begin{array}{c}-0.0353 \\
(-0.80)\end{array}$ & $\begin{array}{c}-0.0371 \\
(-0.84)\end{array}$ & $\begin{array}{c}-0.0355 \\
(-0.80)\end{array}$ & $\begin{array}{c}-0.0341 \\
(-0.76)\end{array}$ \\
\hline Positive & $\begin{array}{c}0.0189 \\
(1.03)\end{array}$ & & & & \\
\hline Negative & & $\begin{array}{c}-0.0194^{* * *} \\
(-2.82)\end{array}$ & & & \\
\hline Pessimism & & & $\begin{array}{c}-0.0181^{* * *} \\
(-2.75)\end{array}$ & & \\
\hline Average Pessimism & & & & $\begin{array}{c}-0.00978 \\
(-1.33)\end{array}$ & \\
\hline News Count & & & & & $\begin{array}{c}-0.00000460 \\
(-0.49)\end{array}$ \\
\hline Constant & $\begin{array}{c}-0.0000793 \\
(-0.47)\end{array}$ & $\begin{array}{c}0.000695^{* * *} \\
(2.87)\end{array}$ & $\begin{array}{c}0.000517^{* * *} \\
(2.65)\end{array}$ & $\begin{array}{c}0.000308 \\
(1.46)\end{array}$ & $\begin{array}{c}0.000105 \\
(0.82)\end{array}$ \\
\hline Observations & 1418 & 1418 & 1418 & 1418 & 1418 \\
\hline Adjusted $R^{2}$ & 0.001 & 0.006 & 0.007 & 0.002 & 0.001 \\
\hline
\end{tabular}


Table 22: Japan stock market - 30 minutes

\begin{tabular}{|c|c|c|c|c|c|}
\hline & $\begin{array}{c}(1) \\
\text { Return }_{t}\end{array}$ & $\begin{array}{c}(2) \\
\text { Return }\end{array}$ & $\begin{array}{c}(3) \\
\text { Return } \\
\end{array}$ & $\begin{array}{c}(4) \\
\text { Return }\end{array}$ & $\begin{array}{c}(5) \\
\text { Return } \\
\end{array}$ \\
\hline $\operatorname{Return}_{t-1}$ & $\begin{array}{l}-0.340 \\
(-1.08)\end{array}$ & $\begin{array}{l}-0.340 \\
(-1.10)\end{array}$ & $\begin{array}{l}-0.344 \\
(-1.13)\end{array}$ & $\begin{array}{l}-0.337 \\
(-1.08)\end{array}$ & $\begin{array}{l}-0.332 \\
(-1.04)\end{array}$ \\
\hline Return $_{t-2}$ & $\begin{array}{l}0.179 \\
(0.69)\end{array}$ & $\begin{array}{l}0.205 \\
(0.79)\end{array}$ & $\begin{array}{l}0.204 \\
(0.79)\end{array}$ & $\begin{array}{l}0.183 \\
(0.71)\end{array}$ & $\begin{array}{l}0.185 \\
(0.71)\end{array}$ \\
\hline $\operatorname{Return}_{t-3}$ & $\begin{array}{l}0.323 \\
(1.28)\end{array}$ & $\begin{array}{l}0.313 \\
(1.25)\end{array}$ & $\begin{array}{l}0.315 \\
(1.26)\end{array}$ & $\begin{array}{l}0.335 \\
(1.34)\end{array}$ & $\begin{array}{l}0.318 \\
(1.27)\end{array}$ \\
\hline Return $_{t-4}$ & $\begin{array}{c}0.0701 \\
(0.34)\end{array}$ & $\begin{array}{c}0.0772 \\
(0.37)\end{array}$ & $\begin{array}{l}0.0717 \\
(0.35)\end{array}$ & $\begin{array}{c}0.0722 \\
(0.35)\end{array}$ & $\begin{array}{r}0.0807 \\
(0.39)\end{array}$ \\
\hline $\operatorname{Return}_{t-5}$ & $\begin{array}{c}-0.0982 \\
(-0.49)\end{array}$ & $\begin{array}{l}-0.102 \\
(-0.50)\end{array}$ & $\begin{array}{l}-0.107 \\
(-0.52)\end{array}$ & $\begin{array}{l}-0.101 \\
(-0.50)\end{array}$ & $\begin{array}{c}-0.0932 \\
(-0.47)\end{array}$ \\
\hline Positive & $\begin{array}{c}0.132^{* *} \\
(2.16)\end{array}$ & & & & \\
\hline Negative & & $\begin{array}{c}-0.0736^{* * *} \\
(-2.71)\end{array}$ & & & \\
\hline Pessimism & & & $\begin{array}{c}-0.0767 * * * \\
(-3.17)\end{array}$ & & \\
\hline Average Pessimism & & & & $\begin{array}{c}-0.129 * * * \\
(-2.72)\end{array}$ & \\
\hline News Count & & & & & $\begin{array}{c}0.00000837 \\
(0.31)\end{array}$ \\
\hline Constant & $\begin{array}{c}-0.000955 \\
(-1.43)\end{array}$ & $\begin{array}{c}0.00245^{* * *} \\
(2.80)\end{array}$ & $\begin{array}{c}0.00194^{* * *} \\
(3.16)\end{array}$ & $\begin{array}{c}0.00317^{* * *} \\
(2.85)\end{array}$ & $\begin{array}{c}-0.0000432 \\
(-0.07)\end{array}$ \\
\hline Observations & 718 & 718 & 718 & 718 & 718 \\
\hline Adjusted $R^{2}$ & 0.013 & 0.017 & 0.022 & 0.017 & 0.006 \\
\hline
\end{tabular}

$t$ statistics in parentheses

$* \mathrm{p}<.1,{ }^{* *} \mathrm{p}<.05,{ }^{* * *} \mathrm{p}<.01$ 
Table 23: China stock market - 30 minutes

\begin{tabular}{|c|c|c|c|c|c|}
\hline & $\begin{array}{c}(1) \\
\text { Return }_{t}\end{array}$ & $\begin{array}{c}(2) \\
\text { Return }_{t}\end{array}$ & $\begin{array}{c}(3) \\
\text { Return }_{t}\end{array}$ & $\begin{array}{c}(4) \\
\text { Return }_{t}\end{array}$ & $\begin{array}{c}(5) \\
\text { Return }_{t}\end{array}$ \\
\hline Return $_{t-1}$ & $\begin{array}{c}-0.0618 \\
(-0.35)\end{array}$ & $\begin{array}{c}-0.0855 \\
(-0.49)\end{array}$ & $\begin{array}{c}-0.0795 \\
(-0.46)\end{array}$ & $\begin{array}{c}-0.0747 \\
(-0.43)\end{array}$ & $\begin{array}{c}-0.0740 \\
(-0.43)\end{array}$ \\
\hline Return $_{t-2}$ & $\begin{array}{l}-0.204 \\
(-0.87)\end{array}$ & $\begin{array}{l}-0.221 \\
(-0.94)\end{array}$ & $\begin{array}{l}-0.220 \\
(-0.94)\end{array}$ & $\begin{array}{l}-0.214 \\
(-0.91)\end{array}$ & $\begin{array}{l}-0.211 \\
(-0.90)\end{array}$ \\
\hline $\operatorname{Return}_{t-3}$ & $\begin{array}{l}-0.126 \\
(-0.91)\end{array}$ & $\begin{array}{l}-0.122 \\
(-0.89)\end{array}$ & $\begin{array}{l}-0.128 \\
(-0.93)\end{array}$ & $\begin{array}{l}-0.115 \\
(-0.84)\end{array}$ & $\begin{array}{l}-0.110 \\
(-0.80)\end{array}$ \\
\hline Return $_{t-4}$ & $\begin{array}{l}0.206 \\
(0.83)\end{array}$ & $\begin{array}{l}0.182 \\
(0.73)\end{array}$ & $\begin{array}{l}0.188 \\
(0.76)\end{array}$ & $\begin{array}{l}0.188 \\
(0.76)\end{array}$ & $\begin{array}{l}0.193 \\
(0.77)\end{array}$ \\
\hline $\operatorname{Return}_{t-5}$ & $\begin{array}{c}-0.0670 \\
(-0.32)\end{array}$ & $\begin{array}{c}-0.0696 \\
(-0.33)\end{array}$ & $\begin{array}{c}-0.0725 \\
(-0.34)\end{array}$ & $\begin{array}{c}-0.0743 \\
(-0.35)\end{array}$ & $\begin{array}{c}-0.0622 \\
(-0.30)\end{array}$ \\
\hline Positive & $\begin{array}{c}0.0937 \\
(1.54)\end{array}$ & & & & \\
\hline Negative & & $\begin{array}{c}-0.0438^{*} \\
(-1.93)\end{array}$ & & & \\
\hline Pessimism & & & $\begin{array}{c}-0.0471^{* *} \\
(-2.31)\end{array}$ & & \\
\hline Average Pessimism & & & & $\begin{array}{c}-0.0537 \\
(-1.42)\end{array}$ & \\
\hline News Count & & & & & $\begin{array}{c}0.0000166 \\
\quad(0.78)\end{array}$ \\
\hline Constant & $\begin{array}{c}-0.000329 \\
(-0.49)\end{array}$ & $\begin{array}{c}0.00181^{* *} \\
(2.35)\end{array}$ & $\begin{array}{c}0.00155^{* * *} \\
(2.74)\end{array}$ & $\begin{array}{c}0.00168^{*} \\
(1.92)\end{array}$ & $\begin{array}{c}0.000125 \\
(0.26)\end{array}$ \\
\hline Observations & 730 & 730 & 730 & 730 & 730 \\
\hline Adjusted $R^{2}$ & 0.001 & 0.001 & 0.003 & -0.001 & -0.002 \\
\hline
\end{tabular}

